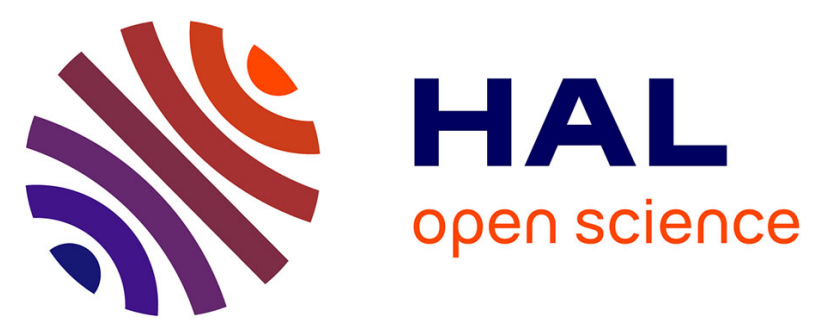

\title{
The synthesis of substituted amino[2.2]paracyclophanes
}

Krishanthi P. Jayasundera, Disraëli N. M. Kusmus, Lise Deuilhé, Leonie

Etheridge, Zane Farrow, David J. Lun, Gurpreet Kaur, Gareth J. Rowlands

\section{To cite this version:}

Krishanthi P. Jayasundera, Disraëli N. M. Kusmus, Lise Deuilhé, Leonie Etheridge, Zane Farrow, et al.. The synthesis of substituted amino[2.2] paracyclophanes. Organic \& Biomolecular Chemistry, 2016, 14 (46), pp.10848-10860. 10.1039/C6OB02150F . hal-01558325

\section{HAL Id: hal-01558325 \\ https://hal-univ-rennes1.archives-ouvertes.fr/hal-01558325}

Submitted on 7 Jul 2017

HAL is a multi-disciplinary open access archive for the deposit and dissemination of scientific research documents, whether they are published or not. The documents may come from teaching and research institutions in France or abroad, or from public or private research centers.
L'archive ouverte pluridisciplinaire HAL, est destinée au dépôt et à la diffusion de documents scientifiques de niveau recherche, publiés ou non, émanant des établissements d'enseignement et de recherche français ou étrangers, des laboratoires publics ou privés. 


\section{The synthesis of substituted amino[2.2]paracyclophanes}

Krishanthi P. Jayasundera, ${ }^{a}$ Disraëli N. M. Kusmus, ${ }^{\mathrm{a}, \mathrm{b}}$ Lise Deuilhé, ${ }^{\mathrm{a}, \mathrm{c}}$ Leonie Etheridge, ${ }^{\mathrm{a}}$ Zane Farrow, ${ }^{\mathrm{a}}$

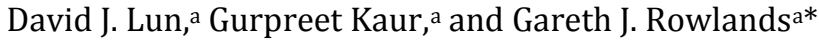

Institute of Fundamental Sciences, Massey University, Private Bag 11 222, Palmerston North, New Zealand.Email: g.j.rowlands@massey.ac.nz

Vrije Universiteit Amsterdam, The Netherlands.

Ecole Nationale Supérieure de Chimie de Rennes, France.

Electronic Supplementary Information (ESI) available: [details of any supplementary information available should be included here]. See DOI: 10.1039/x0xx00000x

Two methodologies for the formation of substituted amino[2.2]paracyclophane derivatives were developed. The first involves the direct amination of bromo[2.2]paracyclophanes with sodium azide. This permits the synthesis of simple mono- and disubstituted derivatives but fails to give sterically congested pseudo-gem derivatives. A 'one-pot' oxidation-Lossen rearrangement of [2.2] paracyclophane oximes provides access to a range of amino[2.2]paracyclophanes including the most efficient synthesis of the pseudo-gem planar chiral amino acid yet reported.

\section{Introduction}

Derivatives of [2.2]paracyclophane offer an intriguing scaffold for the preparation of enantiomerically enriched molecules possessing a plane of chirality, a rigid backbone and unusual electronic properties.1,2,3 These characteristics have been exploited in asymmetric synthesis, ${ }^{1,4}$ as well as probes for the study of through-bond and -space electronic interactions, ${ }^{5}$ interchromophore contact, $\pi-\pi$ electron delocalisation, ${ }^{6}$ photonic applications ${ }^{7}$ as well as precursors to functionalised coatings ${ }^{8,9}$ and atypical bioisosteres. 10,11 While amino[2.2]paracyclophanes (Figure 1) form the basis of many of these functionalised molecules there are few simple, reliable methods for the synthesis of substituted derivatives; most reactions are substrate specific.

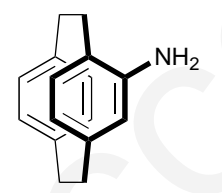

4-amino

[2.2]paracyclophane

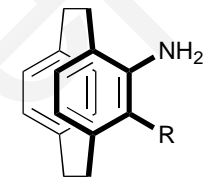

ortho

substituted

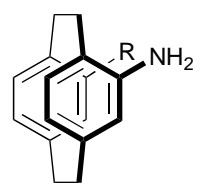

pseudo-gem substituted

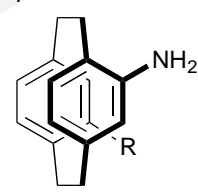

pseudo-ortho substituted

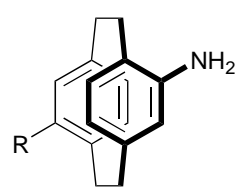

pseudo-para substituted

Fig. 1 Substituted amino[2.2]paracyclophanes. 
The most direct route to 4-amino[2.2] paracyclophane is nitration followed by reduction but this sequence is notoriously problematic. While moderate to high yields have been reported these require very precise reaction times and conditions. ${ }^{8,12,13}$ More common routes to aminoparacyclophanes include the Curtius rearrangement of the appropriate carboxylic acid ${ }^{9,14,15-18}$ or the electrophilic amination of bromoparacyclophanes. Advantages of the former strategy include facile resolution of the acid 12,19 and the ability of acids to direct functionalisation of paracyclophanes. The disadvantages include multiple steps and the use of organic azides. Bromoparacyclophanes are traditionally converted to amines by halogen-metal exchange followed by reaction with an electrophilic amine.18,20-22,23-26 The variable yields for these reactions, in conjunction with the relatively harsh conditions, make this route less attractive.

The palladium-mediated Buchwald-Hartwig amination ${ }^{27}$ of (pseudo)halides offers a direct route to aminoparacyclophanes. ${ }^{15,28,29,30-35}$ It would be reasonable to think this was a general and reliable route but such aminations are substrate specific. For example, the optimum ligand to couple 4-bromo[2.2]paracyclophane with benzylic amines is BINAP ${ }^{30}$ yet this ligand fails ${ }^{32}$ to give satisfactory yields when anilines are used. $\neq$ Ma and Song reported ${ }^{34}$ that a pre-made Pd-dppf complex was the only reagent that coupled benzhydrylideneamine to pseudo-ortho-dibromo[2.2] paracyclophane. And yet the amination of 4-

bromo[2.2]paracyclophane proceeded in a mere $15 \%$ yield under identical conditions. The yield of a monoamination could be increased to $80 \%$ by adding just $1 \mathrm{~mol} \%$ of 4,12 bis(benzhydrylideneamino)[2.2]paracyclophane, the product of the diamination. When the Buchwald-Hartwig amination works it is an excellent route but it is capricious.

Considering the success of copper-mediated aminations, ${ }^{36}$ there is a dearth of reports of this methodology being used on bromo[2.2] paracyclophane. Bolm indicated that the copper-mediated coupling of 4-bromo[2.2]paracyclophane and pyrazole failed ${ }^{31}$ although Paradies ${ }^{12}$ showed that analogous conditions could give the pseudo-gem amino pyrazole but not the imidazole. We have briefly reported the copper-mediated amination of 4-bromo[2.2]paracyclophane ${ }^{24}$ and present a more detailed study below. Ortner has reported an interesting but low yielding transition metal-free amination. ${ }^{10,35}$

During our studies on [2.2] paracyclophane $3,25,26,37,38,39$ we have tested many of the reactions outlined above. At best we found the procedures to be substrate specific with a number being fickle and, in our hands at least, not reproducible. It would be beneficial to develop methodology that furnishes any amino[2.2]paracyclophane regardless of other substituents. Ideally the synthetic sequence should be simple and not involve harsh reagents. The number of synthetic steps was unimportant; rather the guarantee of access to each amine was paramount. In this paper we outline our studies towards this goal. Two methods were investigated, a copper-mediated amination and a more general route based on the Lossen rearrangement.

\section{Results and Discussion}

\section{Copper-mediated amination}


Initially we were attracted to the copper-mediated conversion of aryl bromides to aryl azides as a means of avoiding the use of butyllithium. Previously, we had synthesised azides from 4-lithio[2.2] paracyclophane and tosyl azide then converted this to either a triazole ${ }^{24}$ or reduced it to an amine. ${ }^{25,38}$ We screened a number of literature conditions, changing the source of copper, the base, the solvent, and the temperature of the reaction (Scheme 1).40,41 In each case only a trace of azide was observed with the majority of material being unreacted bromide $\mathbf{1}$. One set of conditions ${ }^{41}$ furnished an appreciable quantity of 4amino[2.2]paracyclophane $\mathbf{2}$ and we were able to optimise these to give the amine $\mathbf{2}$ in moderate $61-69 \%$ yield. Deviation from these conditions inevitably resulted in a dramatic drop in conversion as determined by ${ }^{1} \mathrm{H}$ NMR. Key to good yields was using a sealed vessel with good stirring. Once the reaction has cooled it should be stirred with an aqueous ethylenediaminetetraacetic acid (EDTA) solution for 30 minutes. Failure to follow this procedure results in poor recovery of amine suggesting that coordination with the copper is a problem. Use of microwave irradiation did not decrease reaction time but did result in a cleaner reaction. There is no indication of kinetic resolution.§

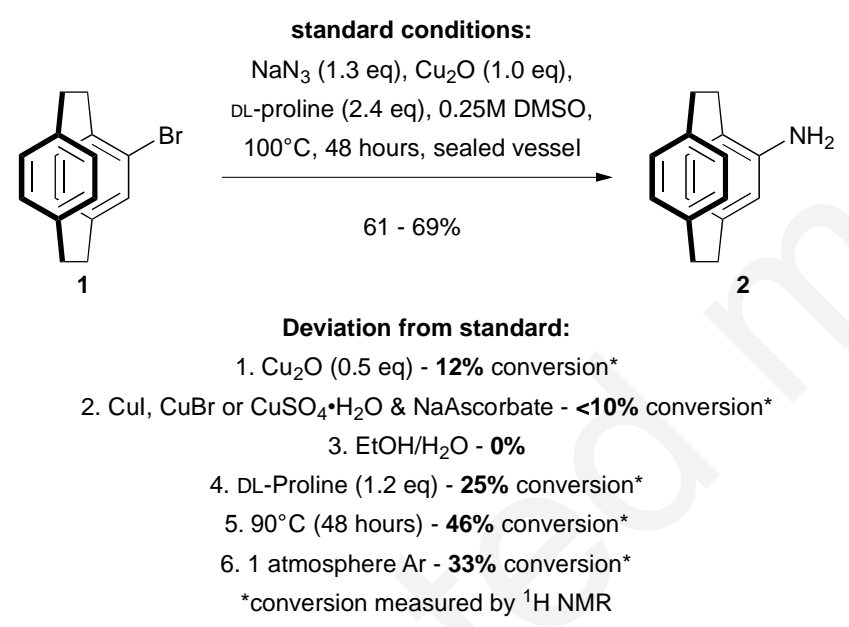

Scheme 1 Optimisation of copper-mediated amination.

The reaction could be applied to dibromo[2.2]paracyclophanes. Both the pseudopara and pseudo-ortho dibromo[2.2]paracyclophanes (3 \& 4) underwent diamination in moderate yield (Scheme 2). Under conventional heating it proved difficult to drive the reactions to completion even with an excess of reagents. In all cases a mixture of the desired diamine $\mathbf{6}$ or $\mathbf{7}$, the mixed amino bromide $\mathbf{8}$, monoamine $\mathbf{2}$ and starting bromide $\mathbf{3}$ or $\mathbf{4}$ were isolated. Extensive optimisation improved the yield so that $50-60 \%$ of the diamine could be routinely isolated. Use of microwave heating did not alter reaction time but permitted less reagent to be used and resulted in good conversion to the diamine $\mathbf{6}$ or $\mathbf{7}$ with only a trace of the other products. The reaction time is important; less than 48 hours and incomplete conversion is observed while more than 48 hours results in the formation of an unidentified side product. As has been noted previously, ${ }^{28}$ the diamines are not stable in solution; if the diamine is left in the reaction mixture decomposition is observed. 


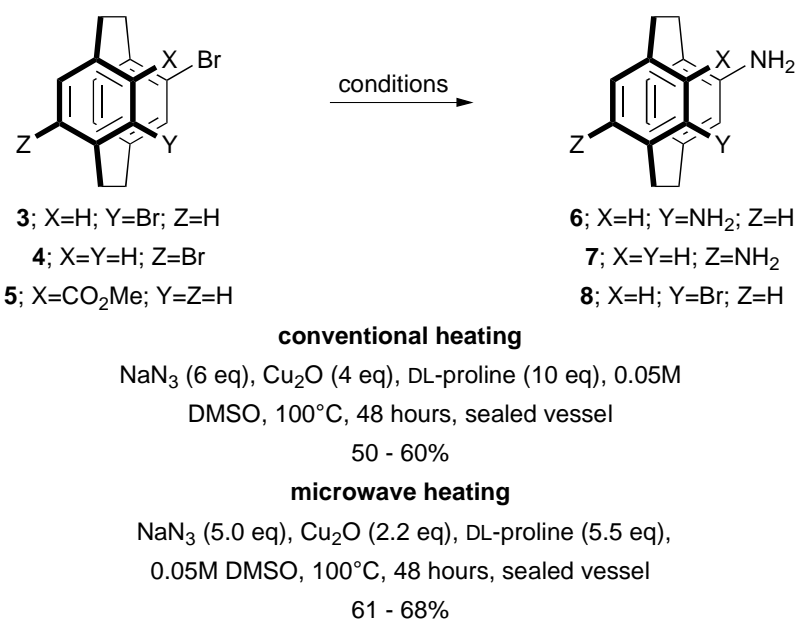

Scheme 2 Amination of substituted [2.2]paracyclophanes.

Amination of the pseudo-gem substituted bromo ester $\mathbf{5}$ was unsuccessful. Unreacted starting material was recovered from the reaction. We speculate that substitution of this bromide is hampered by the ester group located directly above the bromide; steric hindrance could slow or prevent the insertion step by preventing the bromide participating in a three or four atom transition state analogous to that proposed in palladium systems. ${ }^{42}$

\section{'One-pot' oxidation-rearrangement entry to amines}

While the copper methodology furnishes both mono- and diamines, we were unhappy with the lack of generality. Therefore, a second route was developed. For this we returned to classic functional group transformations and a 'one-pot' oxidation-Lossen rearrangement that would convert an oxime to an amine. Three ideas guided our thinking; we knew that the formyl group was readily introduced in a controlled manner through either the Rieche formylation ${ }^{17,43}$ or nucleophilic attack on a formyl amide. ${ }^{23,25,44}$ Secondly, the formyl group provides a means to resolve the planar chirality of [2.2]paracyclophane as demonstrated by Bräse's recent chemistry. ${ }^{43,45}$ Finally there was literature precedent to suggest that an aldehyde could be transformed to an amine through the intermediacy of an oxime and/or hydroxamic acid. ${ }^{46,47}$ This chemistry is complementary to the Curtius rearrangement commonly used in paracyclophane chemistry but with the advantage that the Rieche formylation permits the direct introduction of an aldehyde in a highly regioselective manner using standard aromatic directing effects and/or the transannular effect.§§ 


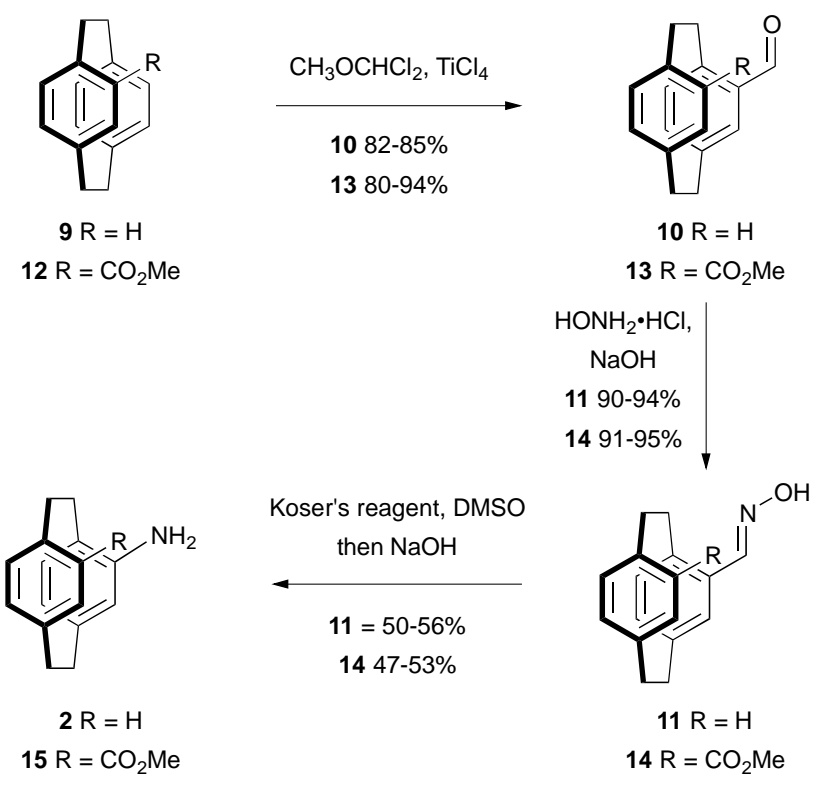

Scheme 3 Synthesis of amino[2.2]paracyclophanes by 'one-pot' oxidation-rearrangement.

The ease of this sequence was demonstrated by the synthesis of 4amino[2.2] paracyclophane (Scheme 3). 4-Formyl[2.2]paracyclophane 10 was prepared by Rieche formylation of $\mathbf{9}$ with dichloromethyl methyl ether and titanium tetrachloride. Formation of the oxime $\mathbf{1 1}$ was followed by a 'one-pot' oxidation-rearrangement sequence. ${ }^{46,47}$ Treating a solution of $\mathbf{1 1}$ in DMSO with Koser's reagent, hydroxy(tosyloxy)iodobenzene $\mathrm{HTIB},{ }^{48}$ for 30 minutes at room temperature and 1 hour at $80^{\circ} \mathrm{C}$ followed by the addition of sodium hydroxide heating for a further 1.5 hours gave 2 in $50-56 \%$ yield. For consistency a number of precautions are needed; all reagents should be dried and finely ground before addition. $46,47,49$

It is assumed that the reaction proceeds by oxidation of the oxime to a hydroxamic acid. This latter species undergoes Lossen rearrangement on treatment with sodium hydroxide. It has been possible to stop the reactions prematurely and isolate the hydroxamic acid. Treatment of the hydroxamic acid with sodium hydroxide gives the desired amine in comparable yield to the 'one-pot' method. ${ }^{47,49}$

The generality of the methodology was confirmed by preparing a number of disubstituted paracyclophanes starting with the known pseudo-gem amino ester $15,{ }^{16}$ and amino bromide 12.33,50,51 Exploiting the transannular effect, the pseudo-gem aldehyde $\mathbf{1 3}^{17}$ could be prepared by directed Rieche formylation of ester 12 (Scheme 3).52 Oxime (14) formation followed by the oxidation-rearrangement sequence gave the desired amine $\mathbf{1 5}$ in moderate to good yield. Key to reproducibility is the use of finely ground and dry reagents; if these precautions are not taken the reaction can stall after the oxidation, furnishing the hydroxamic acid instead of the amine.

The synthesis of the pseudo-gem amino ester compares favourably with literature routes. The ester was first synthesised by the nitration of the ester $\mathbf{1 2}$ followed by 
reduction. The yield of the nitration was 15\%.13,53 Pelter later improved the yield by pseudogem-bromination of an oxazoline followed by halogen-metal exchange, reaction with carbon dioxide, Curtius rearrangement and hydrolysis of the oxazoline. The route was 8 steps from 4-bromo[2.2] paracyclophane and gave the amino acid in 36\% yield.16 Our route is just 5 steps from [2.2] paracyclophane and gives the amino ester in $44 \%$ yield. $\dagger$

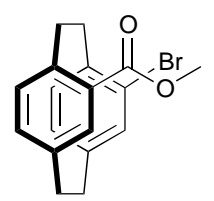

16

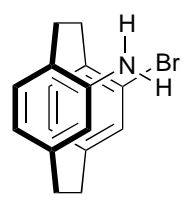

19

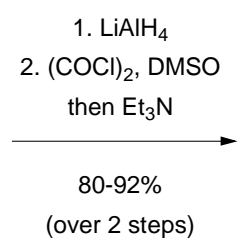

Koser's reagent

then $\mathrm{NaOH}$

$65 \%$

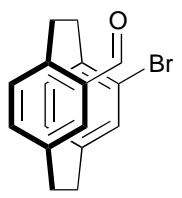

17

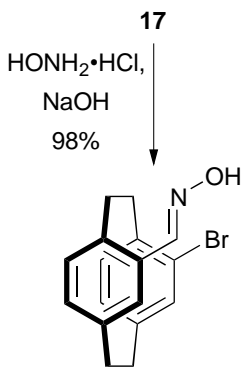

18

Scheme 4 Synthesis of pseudo-gem amino-bromo[2.2]paracyclophane.

4-Amino-13-bromo[2.2]paracyclophane 19 was prepared from ester 12. Aldehyde 17 was synthesised via 16 by regioselective bromination ${ }^{18}$ followed by reduction and Swern oxidation (Scheme 4). A more direct route by either regioselective bromination of 4formyl[2.2]paracyclophane or direct reduction of the ester proved unsatisfactory. The aldehyde was subjected to the standard sequence, oxime 18 formation followed by 'one-pot' oxidation-rearrangement to give 19 in moderate yield. While there are shorter routes to this amine,33,50,51 our goal was to prove the generality of the chemistry. Arguably, this route has the advantage of avoiding a challenging nitration or the use of azides required for the Curtius rearrangement.

Two ortho substituted amino[2.2]paracyclophanes, 5-amino-4methoxy[2.2] paracyclophane $\mathbf{2 5}$ and 4-amino-5-bromo[2.2]paracyclophane 28, were also prepared (Scheme 5). The former was synthesised from the readily available salicylaldehyde analogue 20.54 Initially we tried to form 5-amino-4hydroxy[2.2] paracyclophane $\mathbf{2 2}{ }^{21}$ but the oxidation-rearrangement of $\mathbf{2 1}$ failed. Amino alcohol 22 is unstable and it is possible that it decomposed under the reaction conditions. ${ }^{21}$ The methyl ether $\mathbf{2 5}$ is stable and the standard reaction sequence, aldehyde $\mathbf{2 3}$ to amine $\mathbf{2 5}$ via oxime $\mathbf{2 4}$, proceeded satisfactorily.

4-Amino-5-bromo[2.2] paracyclophane $\mathbf{2 8}$ was prepared from $\mathbf{2 6}$, which is readily available through the elegant chemistry of Bräse. ${ }^{55}$ Once again, 'one-pot' oxidationrearrangement of oxime $\mathbf{2 7}$ delivered the desired amine $\mathbf{2 8}$ in an acceptable yield (Scheme 5). It should be noted that bromo amine $\mathbf{2 8}$ is stunningly unreactive; virtually all attempts 
to elaborate the amine met with failure; various alkylations, reductive aminations, and acylations with anhydrides or acyl chlorides (catalysed and non-catalysed) all returned unreacted starting material. Even heating a mixture of $\mathbf{2 8}$ and base in neat iodomethane failed. The only reaction that gave an identifiable new product was diazotisation followed by reaction with morpholine, which furnished triazene 29 (Scheme 6). Attempts to react the diazonium salt with other nucleophiles, such as $\mathrm{KI}$ and $\mathrm{KBr}$, resulted in the same unidentified product in low yield. The synthesis of ortho substituted [2.2]paracyclophanes is notoriously problematic.
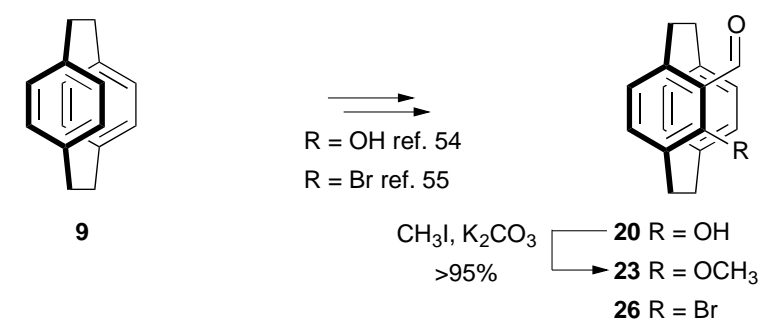

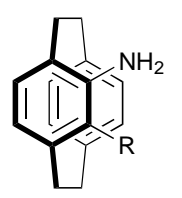

$22 \mathrm{R}=\mathrm{OH} ; 0 \%$ $25 \mathrm{R}=\mathrm{OCH}_{3} ; 59 \%$ $28 \mathrm{R}=\mathrm{Br} ; 56 \%$
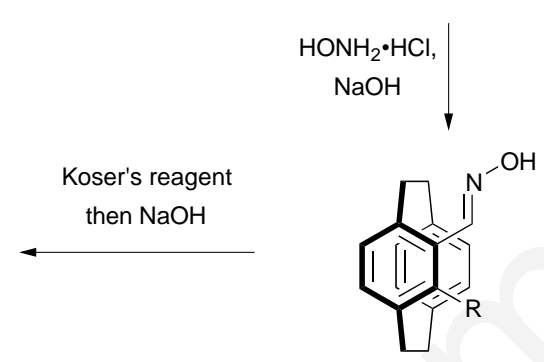

$21 \mathrm{R}=\mathrm{OH} ; 62 \%$ $24 \mathrm{R}=\mathrm{OCH}_{3} ; 83 \%$ $27 \mathrm{R}=\mathrm{Br} ; 94 \%$

Scheme 5 Synthesis of ortho-substituted amino[2.2]paracyclophanes.

\section{Catalysis}

It is known that hydrogen bond donor catalysts and Brønsted acids can promote the Friedel-Crafts-type alkylation of indole with trans- $\beta$-nitrostyrene. ${ }^{12,18,56}$ We were curious if the planar chiral amino acid formed would mediate this reaction. Pseudo-gem amino ester 15 was converted to the sulfonamides 31-33 (Scheme 7). It was hoped that the sulfonamide would increase the potential for hydrogen bonding and create a chiral pocket.

Enantiomerically enriched acids $\mathbf{3 1}$ were prepared by resolution of the planar chirality through selective recrystallisation of the diastereomeric cinchonium salts. While resolution of the pseudo-gem formyl ester $\mathbf{1 3}$ should be possible through the formation of a chiral imine it was more expedient to perform a late stage resolution. Analysis by HPLC, using Chiralpak(R) AD-H column (20:80 iPrOH:Hex @ $1.0 \mathrm{ml} / \mathrm{min}$ ), revealed that neutralisation of the insoluble salt gave the acid with 91:9 er. The other enantiomer could be obtained by a single recrystallisation of the mother liquor as a 6:94 er mixture. Two amides were prepared from the enantiomerically enriched sulfonamides, the bis((3,5trifluoromethyl)anilide $\mathbf{3 2}$ and the $N$-trifluorosulfonamide 33 . These were prepared to alter the steric environment and the acidity of the amide proton compared to the acid proton. 


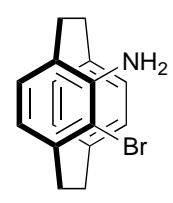

28

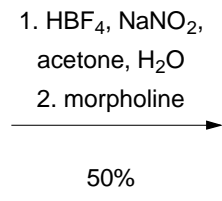

$5 \%$

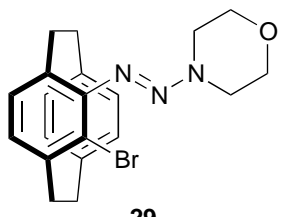

29

Scheme 6 Synthesis of triazene.

We then screened ( \pm )-[2.2] paracyclophane-4-carboxylic acid, sulfonamide $\mathbf{3 1}$, and the two amides $\mathbf{3 2}$ and $\mathbf{3 3}$ in the Friedel-Crafts-type addition of indole to trans- $\beta$ nitrostyrene (Scheme 8). The reactions were evaluated by mixing the substrates and catalyst in $\mathrm{CDCl}_{3}$ then shaking for 24 hours. ${ }^{1} \mathrm{H}$ NMR of the crude reaction mixture gives the conversion while HPLC analysis of the isolated product give the enantioselectivity.
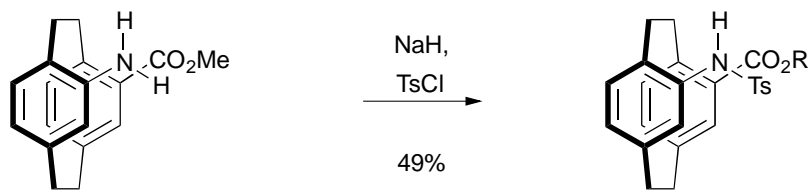

$( \pm)-15$
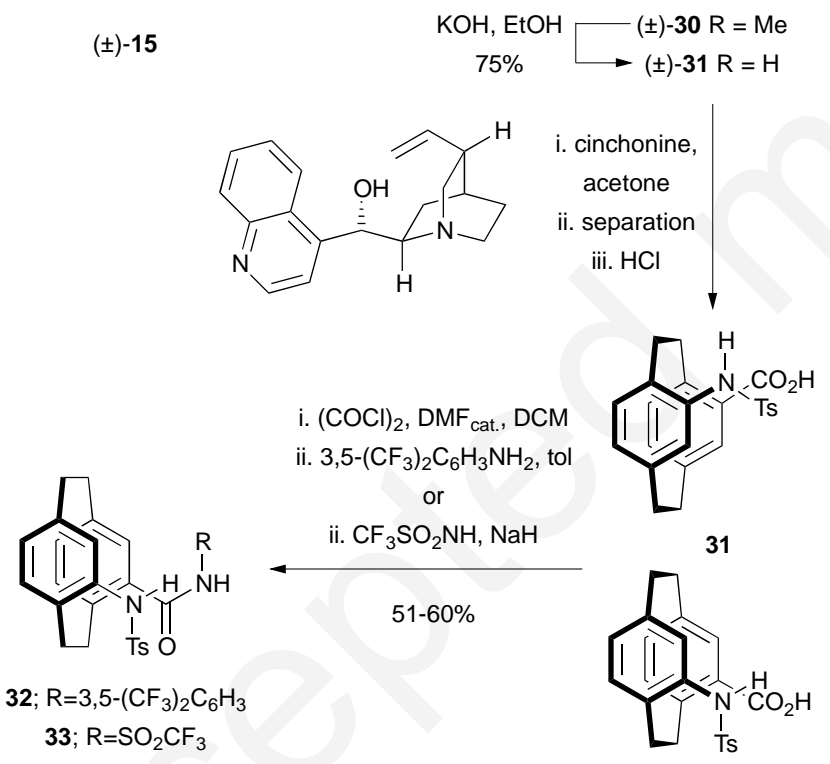

31

Scheme 7 Resolution of planar chiral amino acids. Absolute configuration of the two enantiomers is unknown.

The results show that both the amine and the carboxylic acid functionality are necessary for catalysis; [2.2] paracyclophane-4-carboxylic acid is a poor catalyst. The trifluorosulfonamide 33 gives the most reactive catalyst, permitting over $50 \%$ conversion in 24 hours; presumably as it is the most acidic catalyst. ${ }^{57}$ Unfortunately, none of the reactions occurred with any enantioselectivity. The best results was 52.5:47.5 er (5\% ee) with the simple amino acid derivative $\mathbf{3 1}$. 


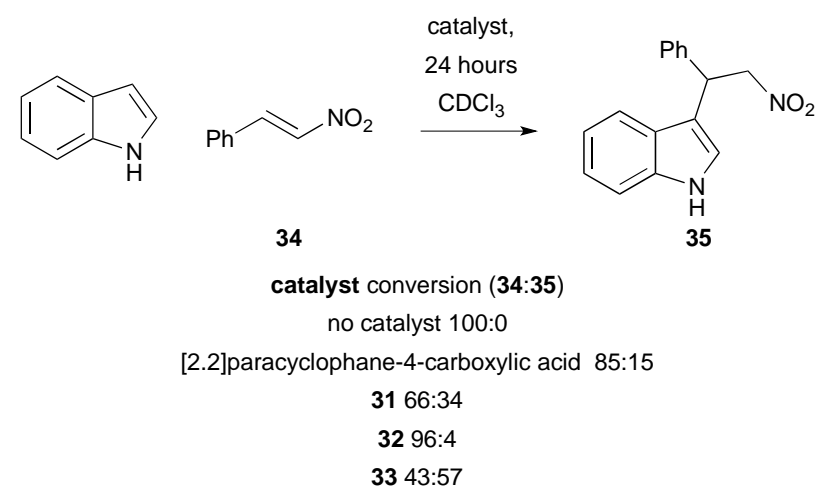

Scheme 8 Acid catalysis of Friedel-Crafts alkylation.

\section{Conclusions}

In conclusion, we have developed two routes to substituted amino[2.2] paracyclophanes. The direct amination of bromo[2.2] paracyclophane gives moderate to good yields of simple amino[2.2] paracyclophanes but fails to give the more sterically demanding pseudo-gem derivatives. The simplicity of the reaction is offset by a use of an excess of sodium azide and a laborious work-up. An alternative reaction sequence is more general. This second route permits the electrophilic aromatic chemistry of [2.2]paracyclophane, and both ortho and transannular directing effects, to be exploited. It has provided the shortest published route to the pseudo-gem planar chiral amino acid. In the future we intend to develop more efficient routes to amino[2.2] paracyclophanes including directed nitrations and to exploit these in the synthesis of planar chiral amino acids for use in asymmetric catalysis.

\section{Experimental}

\section{General information}

All starting compounds and solvents were used as received from commercial sources without further purification unless otherwise noted. All reactions were performed in ovendried glassware under an atmosphere of argon or nitrogen unless otherwise stated. Column chromatography was carried out on silica gel (grade 60, mesh size 230-400, Scharlau). Visualisation techniques employed included using ultraviolet light (254 nm), potassium permanganate, ethanolic phosphomolybdic acid or ninhydrin when applicable. NMR spectra were recorded at room temperature on Bruker-400 and Bruker-500 Avance instruments, with the use of the solvent proton as an internal standard. Melting points were recorded on a Gallenkamp melting point apparatus and are uncorrected. Mass spectra and high resolution mass spectrometry were performed at the Waikato Mass Spectrometry Facility, The University of Waikato, New Zealand.

\section{Copper methodology}

4-Amino[2.2]paracyclophane (2). ${ }^{20,39} \mathrm{~A}$ suspension of 4-bromo[2.2]paracyclophane 1 (1.0 g, 3.48 mmol, 1.0 eq.), $\mathrm{NaN}_{3}$ (0.45 g, 6.96 mmol, 2.0 eq.), $\mathrm{Cu}_{2} \mathrm{O}$ (0.50 g, $3.48 \mathrm{mmol}, 1.0$ eq.) 
and DL-proline (0.96 g, $8.36 \mathrm{mmol}, 2.4$ eq.) in DMSO (14 ml) in a round bottomed flask sealed with a rubber septum was heated to $100{ }^{\circ} \mathrm{C}$ for 48 hours. The initially red solution became black after 24 hours. After heating the reaction mixture was cooled to rt and poured into a saturated aqueous solution of EDTA $(30 \mathrm{ml})$. The deep blue biphasic mixture was stirred for 30 minutes and filtered through Celite ${ }^{\circledR}$. The filtrate was extracted with EtOAc (3 x $20 \mathrm{ml})$. The combined organic layers were dried $\left(\mathrm{MgSO}_{4}\right)$ and concentrated. The residue was purified by column chromatography eluting Hex/EtOAc 4/1 to afford 4amino[2.2]paracyclophane as a pale yellow solid $(0.48 \mathrm{~g}, 62 \%)$.

$\mathrm{R}_{\mathrm{f}}(4 / 1 \mathrm{Hex} /$ EtOAc $) 0.375$

${ }^{1} \mathrm{H}$ NMR $\left(500 \mathrm{MHz}, \mathrm{CDCl}_{3}\right)$ : 目 $7.17(1 \mathrm{H}, \mathrm{dd}, J=7.8 \mathrm{~Hz}), 6.59(1 \mathrm{H}, \mathrm{dd}, J=1.8,7.8 \mathrm{~Hz}), 6.39(2 \mathrm{H}$, $\mathrm{d}, J=7.8 \mathrm{~Hz}), 6.27(1 \mathrm{H}, \mathrm{d}, J=7.8 \mathrm{~Hz}), 6.13(1 \mathrm{H}, \mathrm{dd}, J=1.7,7.8 \mathrm{~Hz}), 5.38(1 \mathrm{H}, \mathrm{d}, J=1.7 \mathrm{~Hz})$, 3.45 (2H, brs), 3.15-2.93 (7H, m), 2.86-2.79 (1H, m). ${ }^{13} \mathrm{C}$ NMR (125 MHz, $\left.\mathrm{CDCl}_{3}\right)$ : 圆 145.1, $141.2,139.1,139.0,135.4,133.6,132.6,131.6,126.9,124.6,123.0,122.4,35.5,35.1,33.2$, 32.4. Data comparable to that reported in the literature. ${ }^{20,39}$

\section{Copper methodology - conventional heating}

\section{4,12-Diamino[2.2] paracyclophane (6) and 12-bromo-4-amino[2.2]paracyclophane} (8). ${ }^{34} \mathrm{~A}$ suspension of 4,12-dibromo[2.2] paracyclophane 3 ( $0.10 \mathrm{~g}, 0.27 \mathrm{mmol}, 1.0$ eq.), $\mathrm{NaN}_{3}$ ( $0.11 \mathrm{~g}, 1.64 \mathrm{mmol}, 6.0$ eq.), $\mathrm{Cu}_{2} \mathrm{O}(0.16 \mathrm{~g}, 1.09 \mathrm{mmol}, 4.0$ eq.) and DL-proline (0.31 g, 2.73 mmol, 10.0 eq.) in DMSO (5.5 ml) in a round bottomed flask sealed with a rubber septum was heated to $100{ }^{\circ} \mathrm{C}$ for 48 hours. The reaction mixture was cooled to $\mathrm{rt}$ and poured into a saturated aqueous solution of EDTA $(15 \mathrm{ml})$. The deep blue biphasic mixture was stirred for 30 minutes and filtered through Celite ${ }^{\circledR}$. The filtrate was extracted with EtOAc $(3 \times 10 \mathrm{ml})$. The combined organic layers were dried $\left(\mathrm{MgSO}_{4}\right)$ and concentrated. The residue was purified by column chromatography using gradient elution starting from Hex/EtOAc; 3/1 to Hex/EtOAc 0/100 to afford 12-bromo-4-amino[2.2]paracyclophane 6 (0.018 g, 22\%) and 4,12-Diamino[2.2] paracyclophane $8(0.033,51 \%)$.

4,12-Diamino[2.2]paracyclophane 6. ${ }^{1} \mathrm{H}$ NMR (400 MHz, $\left.\mathrm{CDCl}_{3}\right)$ : 匇目6.39 (2H, $\mathrm{d}, J=7.7$ $\mathrm{Hz}), 6.20(2 \mathrm{H}, \mathrm{d}, J=1.2 \mathrm{~Hz}), 6.07(2 \mathrm{H}, \mathrm{dd}, J=7.7,1.3 \mathrm{~Hz}), 3.36(4 \mathrm{H}, \mathrm{brs}), 3.09-3.03(2 \mathrm{H}, \mathrm{m})$, 2.98-2.89 (4H, m), 2.68-2.60 (2H, m). ${ }^{13} \mathrm{C}$ NMR (125 MHz, $\left.\mathrm{CDCl}_{3}\right)$ : ? ? 144.7, 141.3, 135.2, 124.3. 123.1, 116.3, 32.7, 32.0. Data comparable to that reported in the literature. ${ }^{34}$

4-Amino-12-bromo[2.2]paracyclophane 8. ${ }^{1} \mathrm{H}$ NMR $\left(500 \mathrm{MHz}, \mathrm{CDCl}_{3}\right)$ : ? $07.29(1 \mathrm{H}, \mathrm{d}, J=$ $1.5 \mathrm{~Hz}), 6.60(1 \mathrm{H}, \mathrm{d}, J=7.8 \mathrm{~Hz}), 6.44(1 \mathrm{H}, \mathrm{dd}, J=7.8,1.4 \mathrm{~Hz}), 6.37(1 \mathrm{H}, \mathrm{d}, J=7.7 \mathrm{~Hz}), 6.16$ $(1 \mathrm{H}, \mathrm{dd}, J=7.7,1.5 \mathrm{~Hz}), 6.11(1 \mathrm{H}, \mathrm{d}, J=1.4), 3.53(2 \mathrm{H}, \mathrm{brs}), 3.39$ (1H, ddd, $J=12.4,9.8,2.0$ $\mathrm{Hz}), 3.15-3.11(1 \mathrm{H}, \mathrm{m}), 3.09-2.91(4 \mathrm{H}, \mathrm{m}), 2.82(1 \mathrm{H}, \mathrm{ddd}, J=13.1,10.0,6.6 \mathrm{~Hz}), 2.68(1 \mathrm{H}$, ddd, $J=13.5,9.4,7.5 \mathrm{~Hz}) .{ }^{13} \mathrm{C}$ NMR $\left(125 \mathrm{MHz}, \mathrm{CDCl}_{3}\right)$ : ? $0144.9,141.3,141.1,138.3,135.3$, $134.4,131.9,131.0,125.9,124.3,122.7,117.6,35.5,32.9,32.3,32.1$. Data comparable to that reported in the literature. ${ }^{34}$

\section{Copper methodology - microwave heating}


4,16-Diamino[2.2]paracyclophane (7).28,34 Data comparable to that reported in the literature. ${ }^{28,34}$ It should be noted that this diamine is the least stable amine we have prepared. Purification is best achieved by recrystallisation from hot 1,4-dioxane with the addition of hexane. The amine is best used directly after synthesis. In solution decomposition observable in less than 24 hours. ${ }^{1} \mathrm{H}$ NMR $\left(500 \mathrm{MHz}, \mathrm{CDCl}_{3}\right)$ : 0 ?6.64 $(2 \mathrm{H}, \mathrm{d}, \mathrm{J}$ $=7.9 \mathrm{~Hz}), 6.23(2 \mathrm{H}, \mathrm{d}, J=7.7 \mathrm{~Hz}), 5.51(2 \mathrm{H}, \mathrm{s}), 3.19(2 \mathrm{H}, \mathrm{ddd}, J=12.4,9.7,1.6 \mathrm{~Hz}), 3.05(2 \mathrm{H}$, ddd, $J=15.6,9.9,5.9 \mathrm{~Hz}), 2.91(2 \mathrm{H}, \mathrm{ddd}, J=12.7,10.8,1.9 \mathrm{~Hz}), 2.69(2 \mathrm{H}, \mathrm{ddd}, J=16.4,10.7$, $5.7 \mathrm{~Hz}) .{ }^{13} \mathrm{C}$ NMR (125 MHz, DMSO): ?⿴囗1 $147.3,139.9,134.2,122.5,121.7,118.9,32.8,31.6$.

\section{'One-pot' oxidation-rearrangement methodology}

[2.2]Paracyclophane-4-carbaldehyde oxime (11). ${ }^{58}$ A mixture of hydroxylamine hydrochloride ( $0.208 \mathrm{~g}, 3 \mathrm{mmol}, 3.0$ eq.) and $\mathrm{NaOH}(0.124 \mathrm{~g}, 3.1 \mathrm{mmol}, 3.1$ eq.) in EtOH (5 $\mathrm{ml}$ ) was heated to reflux and a solution of 4-formyl[2.2] paracyclophane ${ }^{43}(0.236 \mathrm{~g}, 1.0$ mmol, 1.0 eq.) in EtOH ( $5 \mathrm{ml}$ ) was added. The resulting mixture was heated at reflux for 30 min. The suspension was cooled to rt and the solvent was removed. The residue was dissolved in EtOAc $(10 \mathrm{ml})$ and washed with $\mathrm{H}_{2} \mathrm{O}(10 \mathrm{ml})$ and brine $(10 \mathrm{ml})$, dried $\left(\mathrm{MgSO}_{4}\right)$ and the solvent removed to give the desired product 11 as a colourless solid $(0.235 \mathrm{~g}, 94 \%)$.

$\mathrm{R}_{\mathrm{f}}(4 / 1 \mathrm{Hex} / \mathrm{EtOAc}) 0.43$

${ }^{1} \mathrm{H}$ NMR $\left(500 \mathrm{MHz}, \mathrm{CDCl}_{3}\right)$ : $⿴ 囗 20.16(1 \mathrm{H}, \mathrm{s}), 7.48(1 \mathrm{H}, \mathrm{brs}), 6.77(1 \mathrm{H}, \mathrm{d}, J=1.1 \mathrm{~Hz}), 6.66(1 \mathrm{H}$, $\mathrm{d}, J=7.8 \mathrm{~Hz}), 6.56(1 \mathrm{H}, \mathrm{dd}, J=7.8,1.9 \mathrm{~Hz}), 6.53-6.43(4 \mathrm{H}, \mathrm{m}), 3.62-3.56(1 \mathrm{H}, \mathrm{m}), 3.20-2.84$ $(7 \mathrm{H}, \mathrm{m}) \cdot{ }^{13} \mathrm{C} \mathrm{NMR}\left(125 \mathrm{MHz}, \mathrm{CDCl}_{3}\right)$ :

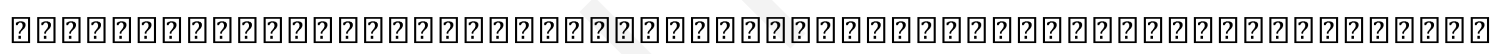

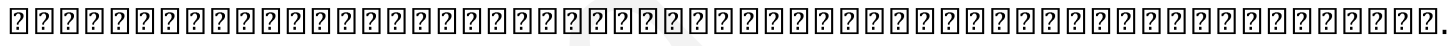

Data comparable to that reported in the literature. ${ }^{58}$

4-Amino[2.2]paracyclophane (2).20,39 A mixture of 4-(hydroxyimino)[2.2]paracyclophane 11 ( 0.50 g, $2.0 \mathrm{mmol}, 1.0$ eq.) and Koser's reagent (1.09 g, $2.8 \mathrm{mmol}, 1.4$ eq.) in DMSO (2 ml) was allow to stirred at $\mathrm{rt}$ for $30 \mathrm{~min}$ and then heated at $80^{\circ} \mathrm{C}$ for $1 \mathrm{~h}$. Sodium hydroxide $(120$ $\mathrm{mg}, 3.0 \mathrm{mmol}, 1.5 \mathrm{eq}$.) was added and heating was continued for further $1.5 \mathrm{~h}$. The mixture was allowed to cool to $\mathrm{rt}$, water $(1 \mathrm{~mL})$ was added and then extracted with ethyl acetate $(2 \mathrm{x}$ $20 \mathrm{~mL})$. The combined organic layer was washed with water $(20 \mathrm{~mL})$, brine and dried over $\mathrm{MgSO}_{4}$ and the solvent was removed under reduced pressure. The resulting residue was separated by column chromatography eluting Hex/EtOAc 9/1 to afford the 4amino[2.2]paracyclophane as a pale yellow solid (240 mg, 54\%). Data as before (see above).

Methyl 13-formyl[2.2] paracyclophane-4-carboxylate (13). ${ }^{17}$ To a solution of methyl [2.2] paracyclophane-4-carboxylate 12 (0.266 g, $1.0 \mathrm{mmol}, 1.0$ eq.) in dry $\mathrm{CH}_{2} \mathrm{Cl}_{2}$ (10 ml) was added $\mathrm{TiCl}_{4}(0.220 \mathrm{ml}, 2.0 \mathrm{mmol}, 2.0$ eq.), and 1,1-dichloromethyl methyl ether $(0.093$ ?. $\mathrm{l}$, $1.05 \mathrm{mmol}, 1.05 \mathrm{eq}$.), at $-10^{\circ} \mathrm{C}$. The reaction mixture was warmed to rt overnight. Ice (15 $\mathrm{ml}$ ) was added and the reaction mixture stirred for $30 \mathrm{~min}$. The aqueous layer was extracted with $\mathrm{CH}_{2} \mathrm{Cl}_{2}(2 \times 20 \mathrm{ml})$. The combined organic layers were washed with a sat. 
aqueous $\mathrm{NaHCO}_{3}$ solution (15 ml), $\mathrm{H}_{2} \mathrm{O}(15 \mathrm{ml})$ and dried $\left(\mathrm{MgSO}_{4}\right)$. The solvent was removed to afford the desired aldehyde 13 as a colourless solid $(0.280 \mathrm{~g}, 94 \%)$.

$\mathrm{R}_{\mathrm{f}}(4 / 1 \mathrm{Hex} /$ EtOAc $) 0.63$

${ }^{1} \mathrm{H}$ NMR $\left(500 \mathrm{MHz} \mathrm{CDCl}_{3}\right)$ : 团9.92 (1H, s), $7.07(2 \mathrm{H}, \mathrm{t}, J=2.4, \mathrm{~Hz}), 6.70(2 \mathrm{H}, \mathrm{ddd}, J=8.7,6.7$, $1.8 \mathrm{~Hz}), 6.64(1 \mathrm{H}, \mathrm{d}, J=15.6 \mathrm{~Hz}), 6.63(1 \mathrm{H}, \mathrm{d}, J=15.6 \mathrm{~Hz}), 4.20-4.02(2 \mathrm{H}, \mathrm{m}), 3.81(3 \mathrm{H}, \mathrm{s})$, 3.20-3.08 (5H, m), 3.03-2.98 (1H, m). ${ }^{13} \mathrm{C}$ NMR (125 MHz, $\left.\mathrm{CDCl}_{3}\right)$ : ?190.9, 174.9, 144.0, $143.7,142.3,140.3,139.9,138.4,136.4,136.2,135.9,134.9,134.7,133.9$, 52.1, 35.2, 34.9, 34.8, 31.3. Data comparable to that reported in the literature. ${ }^{17}$

Methyl 13-((hydroxyimino)methyl)[2.2]paracyclophane-4-carboxylate (14). To a mixture of hydroxylamine hydrochloride $(0.208 \mathrm{~g}, 3.0 \mathrm{mmol}, 3.0$ eq.) and $\mathrm{NaOH}(0.124 \mathrm{~g}, 3.1$ mmol, 3.1 eq.) in ethanol ( $10 \mathrm{ml})$ at reflux was added a solution of methyl 13formyl[2.2]paracyclophane-4-carboxylate $\mathbf{1 3}$ (0.294 g, $1.0 \mathrm{mmol}, 1.0 \mathrm{eq}$.) in EtOH (30 ml). The resulting mixture was heated to reflux for $30 \mathrm{~min}$. The reaction was cooled to $\mathrm{rt}$ and the solvent removed. The residue was extracted with EtOAc $(10 \mathrm{ml})$ and the organic layer washed with $\mathrm{H}_{2} \mathrm{O}(10 \mathrm{ml})$, and brine $(10 \mathrm{ml})$, dried $\left(\mathrm{MgSO}_{4}\right)$ and the solvent removed to give 14 as a colourless solid $(0.288 \mathrm{~g}, 93 \%)$.

$\mathrm{R}_{\mathrm{f}}(4 / 1 \mathrm{Hex} /$ EtOAc $) 0.15$

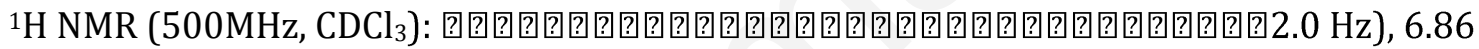

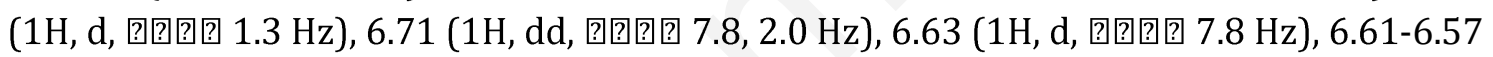
$(2 \mathrm{H}, \mathrm{m}), 4.30-4.25(1 \mathrm{H}, \mathrm{m}), 3.91(3 \mathrm{H}, \mathrm{s}), 3.72-3.68(1 \mathrm{H}, \mathrm{m}), 3.19-3.01(6 \mathrm{H}, \mathrm{m})$ ? ${ }^{13} \mathrm{C} \mathrm{NMR}$ (125 MHz, $\mathrm{CDCl}_{3}$ ): 0 10167.1, 149.3, 142.7, 139.8, 139.6, 139.5, 136.5, 136.3, 135.1, 134.5, 134.3, 132.2, 130.5, 129.5, 51.9, 34.9, 34.8, 34.8, 32.4. HRMS (EI) found: [M+Na]+ 332.1260. $\mathrm{C}_{19} \mathrm{H}_{19} \mathrm{~N}_{1} \mathrm{O}_{3} \mathrm{Na}$ requires $[\mathrm{M}+\mathrm{Na}]+332.1257$.

Methyl 4-amino[2.2]paracyclophane-13-carboxylate (15). ${ }^{16}$ A mixture of finely ground methyl 13-((hydroxyimino)methyl)[2.2] paracyclophane-4-carboxylate 14 (0.155 g, 0.5 mmol, 1.0 eq.) and finely ground Koser's reagent ( $0.272 \mathrm{~g}, 0.7 \mathrm{mmol}, 1.4 \mathrm{eq}$.) in DMSO (1 ml) was stirred at rt for $30 \mathrm{~min}$ and then heated to $80^{\circ} \mathrm{C}$ for $1 \mathrm{~h}$. Finely ground $\mathrm{NaOH}(0.028 \mathrm{~g}$, $0.7 \mathrm{mmol}, 1.4 \mathrm{eq}$.) was added and the heating continued for $1.5 \mathrm{~h}$. The mixture was cooled to $\mathrm{rt}$ and $\mathrm{H}_{2} \mathrm{O}(10 \mathrm{ml})$ added. The aqueous layer was extracted with EtOAc $(3 \times 10 \mathrm{ml})$ and the combined organics washed with $\mathrm{H}_{2} \mathrm{O}(5 \mathrm{ml})$ and brine $(5 \mathrm{ml})$. The combined organic layers were dried $\left(\mathrm{MgSO}_{4}\right)$ and the solvent removed. The resulting residue was separated by column chromatography eluting Hex/EtOAc; 9/1 to afford the methyl 4amino[2.2]paracyclophane-13-carboxylate 15 as a colourless solid (0.075 g, 53\%).

$\mathrm{R}_{\mathrm{f}}(4 / 1 \mathrm{Hex} /$ EtOAc $) 0.38$

${ }^{1} \mathrm{H}$ NMR $\left(500 \mathrm{MHz}, \mathrm{CDCl}_{3}\right)$ : ?] $7.23(1 \mathrm{H}, \mathrm{d}, J=1.9 \mathrm{~Hz}), 6.68(1 \mathrm{H}, \mathrm{dd}, J=7.7,1.9 \mathrm{~Hz}), 6.41(1 \mathrm{H}$, d, $J=7.8 \mathrm{~Hz}), 6.34(1 \mathrm{H}, \mathrm{d}, J=7.8 \mathrm{~Hz}), 6.18(1 \mathrm{H}, \mathrm{dd}, J=7.7,1.9 \mathrm{~Hz}), 5.48(1 \mathrm{H}, \mathrm{d}, J=1.5 \mathrm{~Hz})$, $4.28(1 \mathrm{H}, \mathrm{ddd}, J=13.5,9.8,5.2 \mathrm{~Hz}), 3.88(3 \mathrm{H}, \mathrm{s}), 3.16(1 \mathrm{H}, \mathrm{ddd}, J=13.0,9.8,2.9 \mathrm{~Hz}), 3.07-$ $2.90(5 \mathrm{H}, \mathrm{m}), 2.74(1 \mathrm{H}, \mathrm{ddd}, J=14.0,10.7,5.2 \mathrm{~Hz}) .{ }^{13} \mathrm{C} \mathrm{NMR}\left(125 \mathrm{MHz}, \mathrm{CDCl}_{3}\right)$ : ?? 169.2 , 
$142.0,140.8,138.9,136.4,135.5,135.0,133.8,127.5,124.9,122.9,121.3,51.8,35.0,34.8$, $31.9,31.5$. Data comparable to that reported in the literature. 16

Methyl 13-bromo[2.2] paracyclophane-4-carboxylate (16). ${ }^{18}$ To a two-necked round bottom flask charged with iron filings $(0.067 \mathrm{~g}, 1.2 \mathrm{mmol}, 0.3 \mathrm{eq}$.) covered with foil was fitted a dropping funnel filled with $\mathrm{Br}_{2}\left(0.206\right.$ ? $\mathrm{l}, 4.0 \mathrm{mmol}, 1.0$ eq.) in $\mathrm{CH}_{2} \mathrm{Cl}_{2}$ (20 ml) (the stock solution). Stock solution ( $2 \mathrm{ml}$ ) was added to the iron filings and stirred for $30 \mathrm{~min}$ at rt. A solution of methyl [2.2]paracyclophane-4-carboxylate 12 (1.06 g, $4.0 \mathrm{mmol}, 1.0 \mathrm{eq}$ ) in dry $\mathrm{CH}_{2} \mathrm{Cl}_{2}(20 \mathrm{ml})$ was added and the stock solution was then added dropwise over $1 \mathrm{~h}$. The resulting mixture was stirred for $1 \mathrm{~h}$ at $\mathrm{rt}$. The mixture was washed with sat. aqueous $\mathrm{Na}_{2} \mathrm{~S}_{2} \mathrm{O}_{3}(30 \mathrm{ml})$ and brine $(30 \mathrm{ml})$ and dried $\left(\mathrm{MgSO}_{4}\right)$. The solution was filtered and the solvent was removed under reduced pressure to afford the desire product $\mathbf{1 6}$ as a pale yellow solid (1.28 g, 93\%).

$\mathrm{R}_{\mathrm{f}}(9 / 1 \mathrm{Hex} /$ EtOAc $) 0.45$

${ }^{1} \mathrm{H}$ NMR (500 MHz, $\left.\mathrm{CDCl}_{3}\right)$ : ? ? $7.35(1 \mathrm{H}, \mathrm{d}, J=1.9 \mathrm{~Hz}), 6.69(1 \mathrm{H}, \mathrm{dd}, J=7.8,1.9 \mathrm{~Hz}), 6.60(1 \mathrm{H}$, d, $J=1.9 \mathrm{~Hz}), 6.57-6.54(3 \mathrm{H}, \mathrm{m}), 4.43-4.37(1 \mathrm{H}, \mathrm{m}), 3.89(3 \mathrm{H}, \mathrm{s}), 3.22-3.01(1 \mathrm{H}, \mathrm{m}), 3.15-2.92$ (6H, m). ${ }^{13} \mathrm{C}$ NMR (125 MHz, $\left.\mathrm{CDCl}_{3}\right)$ : 国167.5, 142.8, 141.4, 139.2, 139.2, 136.6, 136.5, $136.2,134.9,134.5,131.7,128.6,127.3,51.7,35.3,35.0,34.7,33.7$. Data comparable to that reported in the literature. 18

13-Bromo-4-hydroxymethyl[2.2]paracyclophane. To a suspension of $\mathrm{LiAlH}_{4}$ (84 mg, 2.2 mmol, 2.2 eq.) in THF (4 ml) was added a solution of methyl 13-bromo[2.2]paracyclophane4-carboxylate 16 (345 mg, $1.0 \mathrm{mmol}, 1.0$ eq.) in THF ( $6 \mathrm{ml}$ ) over $10 \mathrm{~min}$ at rt. The reaction mixture was heated to reflux for $2 \mathrm{~h}$ and then cooled to $\mathrm{rt}$. The excess hydride was destroyed by the addition of aqueous $2 \mathrm{M} \mathrm{HCl}(5 \mathrm{ml})$. The suspension was filtered through celite, washing with $\mathrm{CH}_{2} \mathrm{Cl}_{2}$ and diluted with $\mathrm{CH}_{2} \mathrm{Cl}_{2}(20 \mathrm{ml})$. The aqueous layer was extracted with $\mathrm{CH}_{2} \mathrm{Cl}_{2}(2 \times 10 \mathrm{ml})$. The combined organic layers were washed with sat. aqueous $\mathrm{NaHCO}_{3}$ $(10 \mathrm{ml}), \mathrm{H}_{2} \mathrm{O}(10 \mathrm{ml})$, brine $(10 \mathrm{ml})$, and dried $\left(\mathrm{MgSO}_{4}\right)$. The solvent was removed to afford the 13-bromo-4-hydroxymethyl[2.2]paracyclophane as a colourless solid, which was used for the next reaction without further purification (315 $\mathrm{mg}$, quant.).

$\mathrm{R}_{\mathrm{f}}(9 / 1 \mathrm{Hex} / \mathrm{EtOAc}) 0.1$

${ }^{1} \mathrm{H} \mathrm{NMR}\left(500 \mathrm{MHz}, \mathrm{CDCl}_{3}\right)$ : 国6.60 (1H, dd, $\left.J=7.8,1.9 \mathrm{~Hz}\right), 6.55-6.45(4 \mathrm{H}, \mathrm{m}), 6.39(1 \mathrm{H}, \mathrm{d}, J=$ $1.5 \mathrm{~Hz}), 4.71(1 \mathrm{H}, \mathrm{d}, J=12.7 \mathrm{~Hz}), 4.38(1 \mathrm{H}, \mathrm{d}, J=12.7 \mathrm{~Hz}), 3.40(1 \mathrm{H}, \mathrm{ddd}, J=13.1,10.2,2.3$ $\mathrm{Hz}), 3.17-2.97(6 \mathrm{H}, \mathrm{m}) 2.87$ (1H, ddd, $J=16.7,10.8,5.8 \mathrm{~Hz}$ ). ${ }^{13} \mathrm{C}$ NMR $\left(125 \mathrm{MHz}, \mathrm{CDCl}_{3}\right)$ : ?]140.4, 139.9, 139.7, 139.4, 137.4, 137.6, 135.2, 133.5, 133.4, 132.5, 132.3, 132.2, 129.2, $64.7,35.4,35.2,34.5,32.9$.

13-Bromo-4-formyl[2.2]paracyclophane (17). To a solution of oxalyl chloride 0.10 al, $1.15 \mathrm{mmol}, 1.15$ eq.) in dry $\mathrm{CH}_{2} \mathrm{Cl}_{2}(5 \mathrm{ml})$ at $-78^{\circ} \mathrm{C}$ was added DMSO (0.17 $0 \mathrm{l}, 2.40 \mathrm{mmol}$, 2.40 eq.). The solution was stirred for $15 \mathrm{~min}$ at this temperature. A solution of 13-bromo-4hydroxymethyl[2.2] paracyclophane $\left(0.32 \mathrm{~g}, 1.00 \mathrm{mmol}, 1.00 \mathrm{eq}\right.$.) in $\mathrm{CH}_{2} \mathrm{Cl}_{2}(5 \mathrm{ml})$ was slowly added and the reaction stirred for a $15 \mathrm{~min}$ at $-78{ }^{\circ} \mathrm{C}$. $\mathrm{Et}_{3} \mathrm{~N}(0.70$ ? l, $5.00 \mathrm{mmol}, 5.00$ 
eq.) was added and the reaction mixture stirred for a further $1 \mathrm{~h}$ at $-78^{\circ} \mathrm{C}$ and then warmed to $\mathrm{rt}$. The reaction mixture was partitioned between $\mathrm{CH}_{2} \mathrm{Cl}_{2}(10 \mathrm{ml})$ and $\mathrm{H}_{2} \mathrm{O}(10 \mathrm{ml})$. The aqueous layer extracted with $\mathrm{CH}_{2} \mathrm{Cl}_{2}(2 \times 10 \mathrm{ml})$. The combined organic layers were washed with $\mathrm{H}_{2} \mathrm{O}(20 \mathrm{ml})$, dried $\left(\mathrm{MgSO}_{4}\right)$ and the solvent was removed. The resulting residue was purified by column chromatography eluting with Hex/EtOAc 9/1 to afford the 13-bromo-4formyl[2.2]paracyclophane $\mathbf{1 7}$ as a colourless solid (0.29 g, 92\%).

$\mathrm{R}_{\mathrm{f}}(9 / 1 \mathrm{Hex} / \mathrm{EtOAc}) 0.43$

${ }^{1} \mathrm{H} \mathrm{NMR}\left(500 \mathrm{MHz}, \mathrm{CDCl}_{3}\right)$ : ?⿴囗⿱一一)⿴囗十 $10.3(1 \mathrm{H}, \mathrm{s}), 7.10(1 \mathrm{H}, \mathrm{d}, J=1.9 \mathrm{~Hz}), 6.77(1 \mathrm{H}, \mathrm{dd}, J=7.8,1.5$ $\mathrm{Hz}), 6.63(1 \mathrm{H}, \mathrm{dd}, J=7.8,1.5 \mathrm{~Hz}), 6.58(1 \mathrm{H}, \mathrm{d}, J=7.8 \mathrm{~Hz}), 6.53(1 \mathrm{H}, \mathrm{d}, J=7.8 \mathrm{~Hz}), 6.50(1 \mathrm{H}, \mathrm{d}$, $J=1.5 \mathrm{~Hz}), 4.16(1 \mathrm{H}, \mathrm{ddd}, J=10.1,7.3,4.2 \mathrm{~Hz}), 3.55(1 \mathrm{H}, \mathrm{ddd}, J=10.1,6.3,3.2 \mathrm{~Hz}), 3.18-2.93$ $(6 \mathrm{H}, \mathrm{m}) .{ }^{13} \mathrm{C}$ NMR $\left(125 \mathrm{MHz}, \mathrm{CDCl}_{3}\right)$ : ? $0190.9,143.0,141.8,140.2,138.9,138.1,136.9$, 136.4, 136.1, 135.2, 134.0, 131.5, 128.3, 35.6, 35.1, 34.9, 30.4. HRMS (EI) found: [M+Na] ${ }^{+}$ 337.0208. $\mathrm{C}_{17} \mathrm{H}_{15} \mathrm{BrONa}$ requires $[\mathrm{M}+\mathrm{Na}]+337.0198$.

13-Bromo[2.2]paracyclophane-4-carbaldehyde oxime (18). To a mixture of hydroxylamine hydrochloride (.21 g, $3.0 \mathrm{mmol}, 3.0 \mathrm{eq}$.) and $\mathrm{NaOH}(0.12 \mathrm{~g}, 3.1 \mathrm{mmol}, 3.1 \mathrm{eq}$.) in EtOH (10 ml) heated to reflux, was added a solution of 13-bromo-4formyl[2.2]paracyclophane 17 (0.32 g, $1.0 \mathrm{mmol}, 1.0 \mathrm{eq}$.) in ethanol ( $40 \mathrm{ml})$. The resulting mixture was heated to reflux for $30 \mathrm{~min}$. The reaction was cooled to $\mathrm{rt}$ and the solvent removed. The residue was dissolved in EtOAc $(10 \mathrm{ml})$ and washed with $\mathrm{H}_{2} \mathrm{O}(10 \mathrm{ml})$ and brine $(10 \mathrm{ml})$, dried $\left(\mathrm{MgSO}_{4}\right)$ and the solvent removed to give a colourless solid 18 that was used in the next reaction without further purification $(0.33 \mathrm{~g}, 98 \%)$.

$\mathrm{R}_{\mathrm{f}}(4 / 1 \mathrm{Hex} /$ EtOAc $) 0.15$

${ }^{1} \mathrm{H}$ NMR (500 MHz, DMSO-d 6 ): 目回10.88 (1H, s), $8.25(1 \mathrm{H}, \mathrm{s}), 6.79(1 \mathrm{H}, \mathrm{d}, J=1.6 \mathrm{~Hz}), 6.67-$ $6.61(3 \mathrm{H}, \mathrm{m}), 6.59(1 \mathrm{H}, \mathrm{dd}, J=7.7,1.6 \mathrm{~Hz}), 6.55(1 \mathrm{H}, \mathrm{d}, J=7.4 \mathrm{~Hz}), 3.72(1 \mathrm{H}, \mathrm{ddd}, J=17.0$, 13.0, $3.3 \mathrm{~Hz}), 3.38(1 \mathrm{H}, \mathrm{m}), 3.03-2.95(6 \mathrm{H}, \mathrm{m}) .{ }^{13} \mathrm{C}$ NMR (125 MHz, DMSO-d 6 ): ? 141.7, 139.2, 138.1, 137.6, 135.6, 135.5, 135.2, 133.7, 132.3, 132.1, 130.6, 125.3, 34.4, 34.3, 33.9, 31.5. HRMS (EI) found: [M+Na]+352.0307. $\mathrm{C}_{17} \mathrm{H}_{16} \mathrm{BrNONa}$ requires $[\mathrm{M}+\mathrm{Na}]+352.0313$.

4-Amino-13-bromo[2.2]paracyclophane (19). ${ }^{51}$ A mixture of finely ground 13bromo[2.2]paracyclophane-4-carbaldehyde oxime 18 (0.17 g, $0.5 \mathrm{mmol}, 1.0 \mathrm{eq}$.) and finely ground Koser's reagent ( $0.27 \mathrm{~g}, 0.7 \mathrm{mmol}, 1.4 \mathrm{eq}$.) in DMSO ( $1 \mathrm{ml})$ was stirred at rt for 30 min then heated to $80{ }^{\circ} \mathrm{C}$ for $1 \mathrm{~h}$. Finely ground $\mathrm{NaOH}(0.03 \mathrm{~g}, 0.7 \mathrm{mmol}, 1.4$ eq. $)$ was added and heating was continued for $1.5 \mathrm{~h}$. The mixture was cooled to $\mathrm{rt}$ and $\mathrm{H}_{2} \mathrm{O}(1 \mathrm{ml})$ was added. The mixture was extracted with EtOAc $(2 \times 20 \mathrm{ml})$. The combined organic layers were washed with $\mathrm{H}_{2} \mathrm{O}(20 \mathrm{ml})$, dried $\left(\mathrm{MgSO}_{4}\right)$ and the solvent removed. The resulting residue was purified by column chromatography eluting Hex/EtOAc 9/1 to afford 13-bromo-4amino[2.2]paracyclophane 19 as a pale yellow solid (98 $\mathrm{mg}, 65 \%$ ).

$\mathrm{R}_{\mathrm{f}}(4 / 1 \mathrm{Hex} / \mathrm{EtOAc}) 0.53$ 
${ }^{1} \mathrm{H}$ NMR $\left(500 \mathrm{MHz}, \mathrm{CDCl}_{3}\right)$ : 国国6.83 $(1 \mathrm{H}, \mathrm{d}, J=1.8 \mathrm{~Hz}), 6.47(1 \mathrm{H}, \mathrm{dd}, J=17.7,1.5 \mathrm{~Hz}), 6.43$ $(1 \mathrm{H}, \mathrm{d}, J=7.6 \mathrm{~Hz}), 6.40(1 \mathrm{H}, \mathrm{d}, J=7.6 \mathrm{~Hz}), 6.10(1 \mathrm{H}, \mathrm{dd}, J=7.8,1.8 \mathrm{~Hz}), 5.70(1 \mathrm{H}, \mathrm{d}, J=1.8$ $\mathrm{Hz}$ ), 3.69 (1H, ddd, $J=14.1,9.7,2.4 \mathrm{~Hz}), 3.33$ (1H, ddd, $J=13.8,10.3,2.4 \mathrm{~Hz}), 3.13-3.00(2 \mathrm{H}$, m), 2.95-2.83 (4H, m). ${ }^{13} \mathrm{C}$ NMR (125 MHz, $\left.\mathrm{CDCl}_{3}\right)$ : ?147.1, 141.1, 140.7, 138.3, 135.5, 135.5, 135.3, 132.8, 123.6, 123.2, 122.6, 121.2, 35.0, 34.8, 33.2, 31.6. HRMS (EI) found: [M+H] ${ }^{+}$ 302.0554. $\mathrm{C}_{16} \mathrm{H}_{17} \mathrm{BrN}$ requires $[\mathrm{M}+\mathrm{H}]+302.0539$. Data comparable to that reported in the literature. ${ }^{51}$

4-Methoxy-5-formyl[2.2]paracyclophane (23). To a suspension of 4-hydroxy-5formyl[2.2]paracyclophane ${ }^{54} 20$ (0.25 g, $1.0 \mathrm{mmol}, 1.0$ eq.) and $\mathrm{K}_{2} \mathrm{CO}_{3}(0.41 \mathrm{~g}, 3.0 \mathrm{mmol}, 3.0$ eq.) in DMF ( $2 \mathrm{ml}$ ) was added iodomethane ( 0.19 ? $\mathrm{l}, 0.43 \mathrm{~g}, 3.0 \mathrm{mmol}, 3.0$ eq.). The reaction mixture was stirred at $\mathrm{rt}$ for $12 \mathrm{~h}$ then diluted with $\mathrm{H}_{2} \mathrm{O}(10 \mathrm{ml})$. The aqueous layer was extracted with EtOAc $(2 \times 20 \mathrm{ml})$ and dried $\left(\mathrm{MgSO}_{4}\right)$. The solvent was removed and the resulting pale yellow solid was used for the next reaction without further purification $(0.27$ g, quant.).

$\mathrm{R}_{\mathrm{f}}(4 / 1 \mathrm{Hex} / \mathrm{EtOAc}) 0.70$

${ }^{1} \mathrm{H}$ NMR (500 MHz, $\left.\mathrm{CDCl}_{3}\right)$ : ?⿴囗⿱一一)10.11 (1H, s), $6.80(1 \mathrm{H}, \mathrm{dd}, J=7.9,1.9 \mathrm{~Hz}), 6.67(1 \mathrm{H}, \mathrm{d}, J=7.9$ $\mathrm{Hz}), 6.58(1 \mathrm{H}, \mathrm{dd}, J=7.9,1.8 \mathrm{~Hz}), 6.43(1 \mathrm{H}, \mathrm{dd}, J=7.9,1.9 \mathrm{~Hz}), 6.42(1 \mathrm{H}, \mathrm{d}, J=7.6 \mathrm{~Hz}), 6.37$ $(1 \mathrm{H}, \mathrm{dd}, J=7.9,1.9 \mathrm{~Hz}), 4.06(1 \mathrm{H}, \mathrm{ddd}, J=12.2,10.1,1.4 \mathrm{~Hz}), 3.33(1 \mathrm{H}, \mathrm{ddd}, J=13.6,10.1,3.6$ $\mathrm{Hz}), 3.20-3.12(2 \mathrm{H}, \mathrm{m}), 3.10-2.99(2 \mathrm{H}, \mathrm{m}), 2.80-2.73(2 \mathrm{H}, \mathrm{m}) .{ }^{13} \mathrm{C}$ NMR $\left(125 \mathrm{MHz}, \mathrm{CDCl}_{3}\right)$ : ?]192.3, 163.6, 144.4, 141.1, 139.7, 139.4, 133.5, 132.6, 132.0, 131.6, 131.5, 130.0, 129.4, 62.5, 34.4, 34.5, 34.0, 31.0. HRMS (EI) found: $[\mathrm{M}+\mathrm{Na}]+289.1188 . \mathrm{C}_{18} \mathrm{H}_{18} \mathrm{O}_{2} \mathrm{Na}$ requires $[\mathrm{M}+\mathrm{Na}]+289.1199$.

4-Methoxy[2.2]paracyclophane-5-carbaldehyde oxime (24). A mixture of hydroxyl amine hydrochloride ( $0.21 \mathrm{~g}, 3.0 \mathrm{mmol}, 3.0$ eq.) and $\mathrm{NaOH}(0.12 \mathrm{~g}, 3.1 \mathrm{mmol}, 3.1 \mathrm{eq}$.$) in$ EtOH ( $5 \mathrm{ml})$ was heated to reflux before a solution of 4-methoxy-5-

formyl[2.2]paracyclophane 23 ( $0.27 \mathrm{~g}, 1.0 \mathrm{mmol}, 1.0 \mathrm{eq}$.) in EtOH (5 ml) was added. The resulting mixture was heated at reflux for $30 \mathrm{~min}$ then cooled to rt and the solvent removed. The residue was dissolved in EtOAc $(10 \mathrm{ml})$ and washed with $\mathrm{H}_{2} \mathrm{O}(10 \mathrm{ml})$ and brine (10 $\mathrm{ml})$, dried $\left(\mathrm{MgSO}_{4}\right)$ and the solvent removed to give the desired product 24 as a pale yellow solid $(0.24 \mathrm{~g}, 83 \%)$.

$\mathrm{R}_{\mathrm{f}}(4 / 1 \mathrm{Hex} /$ EtOAc $) 0.43$

${ }^{1} \mathrm{H} \mathrm{NMR}\left(500 \mathrm{MHz}, \mathrm{CDCl}_{3}\right)$ : ?⿴囗十) $8.45(1 \mathrm{H}, \mathrm{s}), 8.20(1 \mathrm{H}, \mathrm{s}), 6.80(1 \mathrm{H}, \mathrm{dd}, J=10.0,2.2 \mathrm{~Hz}), 6.51-$ $6.59(3 \mathrm{H}, \mathrm{m}), 6.47(1 \mathrm{H}, \mathrm{dd}, J=8.7,2.2 \mathrm{~Hz}), 6.43(1 \mathrm{H}, \mathrm{d}, J=6.9 \mathrm{~Hz}), 3.83(1 \mathrm{H}, \mathrm{ddd}, J=17.2$, $10.0,1.8, \mathrm{~Hz}), 3.65(3 \mathrm{H}, \mathrm{s}), 3.30(1 \mathrm{H}, \mathrm{ddd}, J=13.4,10.2,3.4 \mathrm{~Hz}), 3.15-3.09(2 \mathrm{H}, \mathrm{m}), 3.03-2.95$ $(2 \mathrm{H}, \mathrm{m}), 2.82-2.68(2 \mathrm{H}, \mathrm{m}) .{ }^{13} \mathrm{C}$ NMR $\left(125 \mathrm{MHz}, \mathrm{CDCl}_{3}\right)$ : ?] 158.4, 148.2, 141.6, 139.5, 139.2, $136.5,133.3,132.6,131.8,131.3,130.5,129.2,126.0,61.7,34.6,34.4,34.0,31.1$. HRMS (EI) found: $[\mathrm{M}+\mathrm{Na}]^{+} 304.1313 . \mathrm{C}_{18} \mathrm{H}_{19} \mathrm{NO}_{2} \mathrm{Na}$ requires $[\mathrm{M}+\mathrm{Na}]+304.1308$.

5-Amino-4-methoxy[2.2]paracyclophane (25). A mixture of finely ground 4methoxy[2.2] paracyclophane-5-carbaldehyde oxime 24 ( $0.23 \mathrm{~g}, 0.8 \mathrm{mmol}, 1.0 \mathrm{eq}$.) and 
finely ground Koser's reagent $(0.44 \mathrm{~g}, 1.1 \mathrm{mmol}, 1.4 \mathrm{eq}$.$) in DMSO (1.6 \mathrm{ml})$ was stirred at $\mathrm{rt}$ for $30 \mathrm{~min}$ and then heated to $80^{\circ} \mathrm{C}$ for $1 \mathrm{~h}$. Finely ground $\mathrm{NaOH}(0.05 \mathrm{~g}, 1.1 \mathrm{mmol}, 1.4 \mathrm{eq}$. $)$ was added and the reaction heated for further $1.5 \mathrm{~h}$. The mixture was cooled to rt and $\mathrm{H}_{2} \mathrm{O}(2$ $\mathrm{ml})$ was added and the aqueous layer extracted with EtOAc $(2 \times 20 \mathrm{ml})$. The combined organic layers were washed with $\mathrm{H}_{2} \mathrm{O}(20 \mathrm{ml})$, dried $\left(\mathrm{MgSO}_{4}\right)$ and the solvent was removed. The resulting residue was separated by column chromatography eluting Hex/EtOAc 9/1 to afford the 5-amino-4-methoxy[2.2]paracyclophane 25 as a colourless solid (0.12 g, 59\%).

$\mathrm{R}_{\mathrm{f}}(4 / 1 \mathrm{Hex} /$ EtOAc $) 0.60$

${ }^{1} \mathrm{H}$ NMR $\left(500 \mathrm{MHz}, \mathrm{CDCl}_{3}\right)$ : 回回6.97 (1H, dd, $\left.J=7.8,1.8 \mathrm{~Hz}\right), 6.64(1 \mathrm{H}, \mathrm{dd}, J=7.8,1.8 \mathrm{~Hz}), 6.53$ $(1 \mathrm{H}, \mathrm{dd}, J=7.8,1.8 \mathrm{~Hz}), 6.43(1 \mathrm{H}, \mathrm{dd}, J=7.8,1.8 \mathrm{~Hz}), 6.18(1 \mathrm{H}, \mathrm{d}, J=7.8 \mathrm{~Hz}), 6.10(1 \mathrm{H}, \mathrm{d}, J=$ $7.8 \mathrm{~Hz}$ ), $3.62(3 \mathrm{H}, \mathrm{s}), 3.17(1 \mathrm{H}, \mathrm{ddd}, J=13.3,9.1,4.2 \mathrm{~Hz}), 3.09-2.90(5 \mathrm{H}, \mathrm{m}), 2.66-2.56(2 \mathrm{H}$, m). ${ }^{13} \mathrm{C}$ NMR (125 MHz, $\mathrm{CDCl}_{3}$ ): 0 ?146.7, 139.1, 139.0, 138.1, 132.7, 132.3, 132.2, 130.2, 128.3, 126.7, 125.9, 124.1, 60.2, 34.3, 33.0, 31.2, 30.7. HRMS (EI) found: $[\mathrm{M}+\mathrm{H}]+254.1548$. $\mathrm{C}_{16} \mathrm{H}_{16} \mathrm{BrN}$ requires $[\mathrm{M}+\mathrm{H}]+254.1539$.

[2.2]Paracyclophane-4-carbaldehyde $\boldsymbol{O}$-methyl oxime. ${ }^{55}$ To a solution of methoxyamine hydrochloride ( $0.10 \mathrm{~g}, 1.2 \mathrm{mmol}, 1.2 \mathrm{eq}$.) and dry pyridine ( 0.32 ? l, $4.0 \mathrm{mmol}, 4.0 \mathrm{eq}$.) in $\mathrm{CH}_{2} \mathrm{Cl}_{2}$ (4 ml) was added 4-formyl[2.2] paracyclophane ( $0.24 \mathrm{~g}, 1.0 \mathrm{mmol}, 1.0 \mathrm{eq}$.) and the reaction mixture stirred at $\mathrm{rt}$ for $12 \mathrm{~h}$. The solvent was removed under reduced pressure. The resulting crude residue was purified by column chromatography eluting Hex/EtOAc $9 / 1$ to afford the [2.2] paracyclophane-4-carbaldehyde $O$-methyl oxime as a colourless solid (240 mg, 91\%).

$\mathrm{R}_{\mathrm{f}}(9 / 1 \mathrm{Hex} /$ EtOAc $) 0.70$

${ }^{1} \mathrm{H} \mathrm{NMR}\left(500 \mathrm{MHz}, \mathrm{CDCl}_{3}\right)$ : ? $8.10(1 \mathrm{H}, \mathrm{s}), 6.79(1 \mathrm{H}, \mathrm{d}, J=1.8 \mathrm{~Hz}), 6.66(1 \mathrm{H}, \mathrm{d}, J=8.0 \mathrm{~Hz})$, 6.56-6.52 (3H, m), 6.53-6.43 (2H, m), $4.04(3 \mathrm{H}, \mathrm{s}), 3.62(1 \mathrm{H}, \mathrm{ddd}, J=13.3,10.0,1.8 \mathrm{~Hz}), 3.20$ $2.96(6 \mathrm{H}, \mathrm{m}), 2.87(1 \mathrm{H}, \mathrm{ddd}, J=17.1,10.3,6.7 \mathrm{~Hz}) .{ }^{13} \mathrm{C} \mathrm{NMR}\left(125 \mathrm{MHz}, \mathrm{CDCl}_{3}\right)$ : 目目148.0, $140.2,139.4,139.3,139.2,135.3,133.9,133.2,133.0,132.9,132.2,132.0,131.0,62.0,35.4$, $35.1,34.9,34.0$. Data comparable to that reported in the literature. 55

5-Bromo[2.2]paracyclophane-4-carbaldehyde $\boldsymbol{O}$-methyl oxime.55 To a solution of $\mathrm{N}$ bromosuccinimide (0.64 g, $3.6 \mathrm{mmol}, 1.2 \mathrm{eq}$ ), $\mathrm{Pd}(\mathrm{OAc})_{2}(0.13 \mathrm{~g}, 0.6 \mathrm{mmol}, 0.2 \mathrm{eq}$.) and AgOTf (0.13 g, $0.6 \mathrm{mmol}, 0.2 \mathrm{eq}$.) in DCE ( $60 \mathrm{ml}$ ), was added [2.2]paracyclophane-4carbaldehyde $O$-methyl oxime $\mathbf{X X}(0.80 \mathrm{~g}, 3.0 \mathrm{mmol}, 1.0 \mathrm{eq}$. $)$ and the reaction mixture was stirred at $100{ }^{\circ} \mathrm{C}$ for $8 \mathrm{~h}$. The reaction was cooled to rt and diluted with $\mathrm{CH}_{2} \mathrm{Cl}_{2}(35 \mathrm{ml})$ and $\mathrm{H}_{2} \mathrm{O}(35 \mathrm{ml})$. Aqueous layer was extracted with $\mathrm{CH}_{2} \mathrm{Cl}_{2}(2 \times 25 \mathrm{ml})$. The combined organic layers were dried $\left(\mathrm{MgSO}_{4}\right)$ and filtered through celite. The solvent was removed and the resulting residue was separated by column chromatography eluting $\mathrm{Hex} / \mathrm{CH}_{2} \mathrm{Cl}_{2} 4 / 1$ to afford 5-bromo[2.2] paracyclophane-4-carbaldehyde $O$-methyl oxime as a colourless solid (0.62 g, 60\%).

$\mathrm{R}_{\mathrm{f}}(9 / 1 \mathrm{Hex} /$ EtOAc $) 0.725$ 
${ }^{1} \mathrm{H}$ NMR (500 MHz, CDCl $)$ : ? $8.15(1 \mathrm{H}, \mathrm{s}), 6.97(1 \mathrm{H}, \mathrm{d}, J=7.6 \mathrm{~Hz}), 6.60-6.49(5 \mathrm{H}, \mathrm{m}), 4.02$ $(3 \mathrm{H}, \mathrm{s}), 3.62-3.46(1 \mathrm{H}, \mathrm{m}), 3.52-3.46(1 \mathrm{H}, \mathrm{m}), 3.19-3.01(4 \mathrm{H}, \mathrm{m}), 2.90-2.87(2 \mathrm{H}, \mathrm{m}) .{ }^{13} \mathrm{C}$ NMR $\left(125 \mathrm{MHz}, \mathrm{CDCl}_{3}\right)$ : 目圂148.9, 141.6, 139.6, 139.0, 134.9, 134.1, 133.4, 133.0, 131.7, 130.0, $129.5,128.4,62.3,36.0,35.0,34.5,33.3$. Data comparable to that reported in the literature. ${ }^{55}$

5-Bromo-4-formyl[2.2]paracyclophane (26). ${ }^{55}$ The solution of 5bromo[2.2]paracyclophane-4-carbaldehyde $O$-methyl oxime (0.095 g, $0.28 \mathrm{mmol}, 1.0 \mathrm{eq}$.), para-toluenesulfonic acid $\left(0.095 \mathrm{~g}, 0.55 \mathrm{mmol}, 2.0 \mathrm{eq}\right.$.), formaldehyde ( $37 \%$ in $\mathrm{H}_{2} \mathrm{O} ; 0.207$ ? $\mathrm{l}, 2.76 \mathrm{mmol}, 10.0$ eq.) in toluene: $\mathrm{H}_{2} \mathrm{O}(10: 1 ; 6 \mathrm{ml})$ was heated to reflux for $12 \mathrm{~h}$. The reaction was cooled to $\mathrm{rt}$ and the solvent removed. The resulting residue was purified by column chromatography eluting Hex/EtOAc 10/1 to afford the 5-bromo-4formyl[2.2] paracyclophane $\mathbf{2 6}$ as a colourless solid (0.080 g, 92\%).

$\mathrm{R}_{\mathrm{f}}(9 / 1 \mathrm{Hex} /$ EtOAc $) 0.70$

${ }^{1} \mathrm{H}$ NMR $\left(500 \mathrm{MHz}, \mathrm{CDCl}_{3}\right)$ : ? $10.08(1 \mathrm{H}, \mathrm{s}), 6.96(1 \mathrm{H}, \mathrm{dd}, J=7.8,1.8 \mathrm{~Hz}), 6.65(1 \mathrm{H}, \mathrm{d}, J=7.8$ $\mathrm{Hz}), 6.61(1 \mathrm{H}, \mathrm{dd}, J=7.8,1.8 \mathrm{~Hz}), 6.61(1 \mathrm{H}, \mathrm{d}, J=7.8 \mathrm{~Hz}), 6.48(1 \mathrm{H}, \mathrm{dd}, J=7.8,1.8 \mathrm{~Hz}), 6.39$ $(1 \mathrm{H}, \mathrm{dd}, J=7.8,1.9 \mathrm{~Hz}), 3.95-3.88(1 \mathrm{H}, \mathrm{m}), 3.62-3.56(1 \mathrm{H}, \mathrm{m}), 3.20-3.16(3 \mathrm{H}, \mathrm{m}), 3.11-3.04$ (1H, m), 2.93-2.78 (2H, m). ${ }^{13} \mathrm{C}$ NMR (125 MHz, $\left.\mathrm{CDCl}_{3}\right)$ : 目国194.2, 144.9, 140.8, 139.8, 139.0, 138.6, 134.5, 134.2, 133.5, 132.9, 132.1, 131.2, 128.6, 35.3, 34.7, 34.5, 33.3. Data comparable to that reported in the literature. 55

5-Bromo[2.2]paracyclophane-4-carbaldehyde oxime (27). To a mixture of hydroxylamine hydrochloride ( $0.16 \mathrm{~g}, 2.3 \mathrm{mmol}, 3.0 \mathrm{eq}$.) and $\mathrm{NaOH}(0.09 \mathrm{~g}, 2.3 \mathrm{mmol}, 3.1$ eq.) in ethanol ( $5 \mathrm{ml}$ ) heated to reflux was added a solution of 5-bromo-4-

formyl[2.2]paracyclophane 26 ( $0.24 \mathrm{~g}, 0.8 \mathrm{mmol}, 1.0 \mathrm{eq}$.) in ethanol (3 ml). The resulting mixture was heated to reflux for $30 \mathrm{~min}$. The reaction was cooled to rt and the solvent was removed. The residue was dissolved in EtOAc $(10 \mathrm{ml})$ and washed with $\mathrm{H}_{2} \mathrm{O}(10 \mathrm{ml})$ and brine $(10 \mathrm{ml})$, dried $\left(\mathrm{MgSO}_{4}\right)$ and the solvent removed to give the desired product 27 as a colourless solid $(0.23 \mathrm{~g}, 94 \%)$.

$\mathrm{R}_{\mathrm{f}}(9 / 1 \mathrm{Hex} /$ EtOAc $) 0.25$

${ }^{1} \mathrm{H}$ NMR $\left(500 \mathrm{MHz}, \mathrm{CDCl}_{3}\right)$ : $20.24(1 \mathrm{H}, \mathrm{s}), 7.65(1 \mathrm{H}, \mathrm{brs}), 7.26(1 \mathrm{H}, \mathrm{s}), 6.98(1 \mathrm{H}, \mathrm{dd}, J=7.8$, $1.8 \mathrm{~Hz}), 6.61(1 \mathrm{H}, \mathrm{d}, J=7.8 \mathrm{~Hz}), 6.60(1 \mathrm{H}, \mathrm{dd}, J=7.8,1.8 \mathrm{~Hz}), 6.53(2 \mathrm{H}, \mathrm{d}, J=7.8 \mathrm{~Hz}), 6.52$ $(1 \mathrm{H}, \mathrm{dd}, J=7.8,1.8 \mathrm{~Hz}), 3.77(1 \mathrm{H}, \mathrm{ddd}, J=13.0,10.1,2.6 \mathrm{~Hz}), 3.50(1 \mathrm{H}, \mathrm{ddd}, J=13.0,10.3,3.4$ $\mathrm{Hz}), 3.30-2.98(4 \mathrm{H}, \mathrm{m}), 2.90-2.82(2 \mathrm{H}, \mathrm{m}) .{ }^{13} \mathrm{C}$ NMR $\left(125 \mathrm{MHz}, \mathrm{CDCl}_{3}\right)$ : 回151.7, 141.7, 140.1, 139.6, 139.1, 135.1, 134.1, 133.4, 133.0, 131.7, 130.3, 129.4, 128.4, 36.1, 34.8, 34.6, 33.3. HRMS (EI) found: [M+Na] $]^{+}, 352.0307 . \mathrm{C}_{17} \mathrm{H}_{16}{ }^{79} \mathrm{BrNONa}$ requires $[\mathrm{M}+\mathrm{Na}]^{+}, 352.0313$.

4-Amino-5-bromo[2.2]paracyclophane (28). A mixture of finely ground 5bromo[2.2]paracyclophane-4-carbaldehyde oxime 27 ( $0.17 \mathrm{~g}, 0.5 \mathrm{mmol}, 1.0 \mathrm{eq}$.) and ground Koser's reagent $(0.27 \mathrm{~g}, 0.7 \mathrm{mmol}, 1.4$ eq.) in DMSO $(1 \mathrm{ml})$ was stirred at rt for $30 \mathrm{~min}$ then heated to $80^{\circ} \mathrm{C}$ for $1 \mathrm{~h}$. Finely ground $\mathrm{NaOH}(0.03 \mathrm{~g}, 0.7 \mathrm{mmol}, 1.4$ eq.) was added and heating was continued for $1.5 \mathrm{~h}$. The mixture was cooled to $\mathrm{rt}, \mathrm{H}_{2} \mathrm{O}(1 \mathrm{ml})$ was added and the 
aqueous layer was extracted with EtOAc $(2 \times 20 \mathrm{ml})$. The combined organic layers were washed with $\mathrm{H}_{2} \mathrm{O}(20 \mathrm{ml})$, dried $\left(\mathrm{MgSO}_{4}\right)$ and the solvent removed. The resulting residue was separated by column chromatography eluting Hex/EtOAc 9/1 to afford 4-amino-5bromo[2.2]paracyclophane $\mathbf{2 8}$ as a pale yellow solid (0.09 g, 56\%).

$\mathrm{R}_{\mathrm{f}}(9 / 1 \mathrm{Hex} /$ EtOAc $) 0.425$

${ }^{1} \mathrm{H}$ NMR $\left(500 \mathrm{MHz}, \mathrm{CDCl}_{3}\right)$ : ? $66.98(1 \mathrm{H}, \mathrm{dd}, J=7.8,1.8 \mathrm{~Hz}), 6.92(1 \mathrm{H}, \mathrm{dd}, J=7.8,1.8 \mathrm{~Hz}), 6.58$ $(1 \mathrm{H}, \mathrm{d}, J=7.8 \mathrm{~Hz}), 6.50(1 \mathrm{H}, \mathrm{dd}, J=7.8,1.8 \mathrm{~Hz}), 6.37(1 \mathrm{H}, \mathrm{d}, J=7.8 \mathrm{~Hz}), 6.18(1 \mathrm{H}, \mathrm{d}, J=7.8$ $\mathrm{Hz}$ ), 3.95 (2H, brs), 3.35 (1H, ddd, $J=17.0,10.1,1.7 \mathrm{~Hz}), 3.15-2.93(5 \mathrm{H}, \mathrm{m}), 2.72-2.83(2 \mathrm{H}$, m). ${ }^{13} \mathrm{C}$ NMR $\left(125 \mathrm{MHz}, \mathrm{CDCl}_{3}\right)$ : $142.7,140.5,138.3,138.2,133.3,132.8,132.5,127.7$, 126.4, 126.0, 124.0, 116.0, 35.8, 33.1, 33.2, 32.4. HRMS (EI) found: [M+H]+ 302.0539. $\mathrm{C}_{16} \mathrm{H}_{17}{ }^{79} \mathrm{BrN}$ requires $[\mathrm{M}+\mathrm{H}]^{+}, 302.0534$.

4-(5-Bromo[2.2]paracyclophan-4-yldiazenyl)morpholine (29). To a solution of 5bromo-4-amino[2.2]paracyclophane 28 (0.075 g, $0.25 \mathrm{mmol}, 1.0$ eq.) in acetone ( $0.1 \mathrm{ml})$, acetonitrile $(0.2 \mathrm{ml})$ and water $(0.5 \mathrm{ml})$ at $0{ }^{\circ} \mathrm{C}$ was added a solution of $50 \%$ aqueous $\mathrm{HBF}_{4}$ $\left(1 \mathrm{ml}\right.$, excess). A solution of $\mathrm{NaNO}_{2}(0.0175 \mathrm{~g}, 0.25 \mathrm{mmol}, 1.0$ eq.) in ice cold water $(0.2 \mathrm{ml})$ was added dropwise at $0{ }^{\circ} \mathrm{C}$. Within 10 minutes a dark yellow percipitate had formed. The solid was removed by filtration and washed with cold $\mathrm{Et}_{2} \mathrm{O}$. The solid was mixed with morpholine $\left(2 \mathrm{ml}\right.$ ) for 2 hours. The solution was diluted with $\mathrm{CH}_{2} \mathrm{Cl}_{2}(10 \mathrm{ml})$ and $\mathrm{H}_{2} \mathrm{O}(10$ $\mathrm{mL})$. The layers were separated and the organic layer washed with $\mathrm{H}_{2} \mathrm{O}(2 \times 10 \mathrm{~mL})$, dried $\left(\mathrm{MgSO}_{4}\right)$ and concentrated. The resulting solid was recyrstalised from $\mathrm{CDCl}_{3}(50 \mathrm{mg}, 50 \%)$.

$\mathrm{R}_{\mathrm{f}}(9 / 1 \mathrm{Hex} /$ EtOAc $) 0.70$

${ }^{1} \mathrm{H}$ NMR $\left(500 \mathrm{MHz}, \mathrm{CDCl}_{3}\right)$ : $077.06(1 \mathrm{H}, \mathrm{dd}, J=6.8,1.2 \mathrm{~Hz}), 6.69(1 \mathrm{H}, \mathrm{dd}, J=6.8,1.2 \mathrm{~Hz})$, 6.58-6.53 (3H, m), 6.41 (1H, d, $J=7.7 \mathrm{~Hz}), 3.94-3.82(8 \mathrm{H}, \mathrm{m}), 3.49(1 \mathrm{H}, \mathrm{ddd}, J=13.1,10.3,2.5$ $\mathrm{Hz}$ ), 3.29 (1H, ddd, $J=12.5,9.8,2.4 \mathrm{~Hz}), 3.17$ (1H, ddd, 15.6, 10.3, $5.2 \mathrm{~Hz}), 3.08-3.00(2 \mathrm{H}, \mathrm{m})$, 2.89-2.80 (2H, m), $2.67(1 \mathrm{H}, \mathrm{ddd}, J=16.3,10.2,6.1 \mathrm{~Hz}) .{ }^{13} \mathrm{C} \mathrm{NMR}\left(125 \mathrm{MHz}, \mathrm{CDCl}_{3}\right)$ : 146.8 , $140.7,139.3,138.8,133.9,133.3,132.9,132.7,131.3,129.9,123.9,66.6,48.01$ (br), 35.6, 34.4, 33.5, 32.9. HRMS (EI) found: $[\mathrm{M}+\mathrm{H}]^{+}, 400.1048 . \mathrm{C}_{20} \mathrm{H}_{23}{ }^{79} \mathrm{BrN}_{3} \mathrm{O}$ requires $[\mathrm{M}+\mathrm{H}]^{+}$, 400.1025 .

Methyl 4-(p-toluenesulfonamido)[2.2]paracyclophane-13-carboxylate (30). To a solution of methyl 4-amino[2.2]paracyclophane-13-carboxylate (1.7 g, $6.0 \mathrm{mmol}, 1.0 \mathrm{eq}$.) in THF (90 ml) at $0^{\circ} \mathrm{C}$ was added $\mathrm{NaH}(60 \% ; 0.29 \mathrm{~g}, 12.0 \mathrm{mmol}, 2.0$ eq.) portionwise over 10 min. The suspension was stirred for 15 minutes whereupon $p$-toluenesulfonyl chloride ( $1.38 \mathrm{~g}, 7.2 \mathrm{mmol}, 1.2 \mathrm{eq}$.) was added in several portions. The suspension was warmed to rt and then heated at reflux overnight. In the morning the suspension was cooled to rt and washed with $\mathrm{H}_{2} \mathrm{O}(4 \times 30 \mathrm{ml})$, dried $\left(\mathrm{MgSO}_{4}\right)$ and concentrated. The residue was purified by column chromatography $\left(\mathrm{SiO}_{2}\right.$; gradient 10:1 hexane:EtOAc to 2:1 Hexane:EtOAc) to give the product 30 (1.29 g, 49\%).

$\mathrm{R}_{\mathrm{f}}(10: 1$ Hex:EtOAc) 0.53 
${ }^{1} \mathrm{H} \mathrm{NMR}\left(500 \mathrm{MHz}, \mathrm{CDCl}_{3}\right)$ : ? $7.36(1 \mathrm{H}, \mathrm{dd}, J=8.3,1.8 \mathrm{~Hz}), 7.35(1 \mathrm{H}, \mathrm{dd}, J=8.3,1.8 \mathrm{~Hz}), 7.12$ $7.09(3 \mathrm{H}, \mathrm{m}), 6.65(1 \mathrm{H}, \mathrm{dd}, J=7.8,1.8 \mathrm{~Hz}), 6.53(1 \mathrm{H}, \mathrm{d}, J=5.2 \mathrm{~Hz}), 6.52(1 \mathrm{H}, \mathrm{d}, J=10.4 \mathrm{~Hz})$, $6.43(1 \mathrm{H}, \mathrm{dd}, J=7.8,1.8 \mathrm{~Hz}), 6.33(1 \mathrm{H}, \mathrm{brs}), 5.94(1 \mathrm{H}, \mathrm{d}, J=1.7 \mathrm{~Hz}), 4.05(1 \mathrm{H}, \mathrm{ddd}, J=13.1$, 10.0, $3.1 \mathrm{~Hz}), 4.00(3 \mathrm{H}, \mathrm{s}), 3.54(1 \mathrm{H}, \mathrm{ddd}, J=13.1,10.0,5.2 \mathrm{~Hz}), 3.12-2.78(6 \mathrm{H}, \mathrm{m}), 2.33(3 \mathrm{H}$, s). ${ }^{13} \mathrm{C}$ NMR $\left(125 \mathrm{MHz}, \mathrm{CDCl}_{3}\right)$ : 国167.4, 143.3, 142.1, 140.7, 139.4, 136.4, 136.3, 136.2, 135.3, 135.2, 134.3, 131.8, 130.9, 129.3, 127.0, 52.6, 34.8, 34.5, 34.3, 31.5, 21.5. HRMS (EI) found: $[\mathrm{M}+\mathrm{Na}]^{+}, 458.1333 . \mathrm{C}_{25} \mathrm{H}_{25} \mathrm{NNaO}_{4} \mathrm{~S}$ requires $[\mathrm{M}+\mathrm{Na}]^{+}, 458.1402$.

4-(p-Toluenesulfonamido)[2.2]paracyclophane-13-carboxylic acid (31). To a solution of methyl 4-( $p$-toluenesulfonamido)[2.2] paracyclophane-13-carboxylate $(0.44 \mathrm{~g}, 1.0 \mathrm{mmol}$, 1.0 eq.) in EtOH (10 ml) was added a solution of $2 \mathrm{M} \mathrm{KOH}(5 \mathrm{ml})$. The resulting mixture was heated to reflux for $5 \mathrm{~h}$. The reaction was cooled in an ice bath, acidified to $\mathrm{pH} 5$ with $2 \mathrm{M} \mathrm{HCl}$ and the resulting precipitate collected by filteration. The precipitate was dissolved in $\mathrm{CH}_{2} \mathrm{Cl}_{2}$ $(10 \mathrm{ml})$,dried $\left(\mathrm{MgSO}_{4}\right)$ and the solvent removed to give 4- $(p$ -

toluenesulfonamido)[2.2] paracyclophane-13-carboxylic acid $\mathbf{3 1}$ as a brownish solid (0.32 $\mathrm{g}$, $75 \%)$. The sample was sufficiently pure to use in the subsequent reactions.

$\mathrm{R}_{\mathrm{f}}(20 / 1 \mathrm{DCM} / \mathrm{MeOH}) 0.30$

${ }^{1} \mathrm{H} \mathrm{NMR}\left(500 \mathrm{MHz}, \mathrm{CDCl}_{3}\right)$ : ?⿴囗十丁7.89 (1H, s), $7.50(2 \mathrm{H}, \mathrm{d}, J=8.2 \mathrm{~Hz}), 7.14(1 \mathrm{H}, \mathrm{d}, J=1.8 \mathrm{~Hz})$, $7.06(2 \mathrm{H}, \mathrm{d}, J=8.2 \mathrm{~Hz}), 6.74(1 \mathrm{H}, \mathrm{dd}, J=7.8,1.8 \mathrm{~Hz}), 6.62(1 \mathrm{H}, \mathrm{d}, J=7.8 \mathrm{~Hz}), 6.53(1 \mathrm{H}, \mathrm{d}, J=$ $7.8 \mathrm{~Hz}), 6.35(1 \mathrm{H}, \mathrm{dd}, J=7.8,1.8 \mathrm{~Hz}), 6.22(1 \mathrm{H}, \mathrm{d}, J=1.8 \mathrm{~Hz}), 4.45-4.38(1 \mathrm{H}, \mathrm{m}), 3.93-3.85$ (1H, m), 3.15-2.86 (6H, m), 2.28 (3H, s). ${ }^{13} \mathrm{C}$ NMR (125 MHz, CDCl 3 ): ?? 172.2, 144.0, 143.4, 140.7, 139.6, 136.9, 136.5, 136.4, 136.1, 136.0, 135.4, 134.8, 131.2, 129.4, 128.2, 128.1, 127.4, 35.9, 34.9, 34.7, 31.2, 21.6. HRMS (EI) found: [M+Na] ${ }^{+}$, 444.1306. $\mathrm{C}_{24} \mathrm{H}_{23} \mathrm{NNaO}_{4} \mathrm{~S}$ requires $[\mathrm{M}+\mathrm{Na}]^{+}, 444.1240$.

\section{Resolution}

To a solution of 4-( $p$-toluenesulfonamido)[2.2]paracyclophane-13-carboxylic acid (1.0 g, $2.38 \mathrm{mmol}, 1.0$ eq.) in $\mathrm{CH}_{2} \mathrm{Cl}_{2}(5 \mathrm{ml})$, a milky suspension of cinchonine in acetone (8 $\left.\mathrm{ml}\right)$ was added dropwise and the resulting mixture was stirred for $1.5 \mathrm{~h}$ at $\mathrm{rt}$. The resulting precipitate was filtered $(0.60 \mathrm{~g})$; this was the first diastereomeric salt. The filtrate was concentrated to give a brownish solid (0.93 g); this was the second diastereomeric salt. Separately, the salts were recrystalised from $\mathrm{CH}_{2} \mathrm{Cl}_{2}$. Separately, the resulting salts were dissolved in $\mathrm{MeOH}(10 \mathrm{ml})$ and $2 \mathrm{M} \mathrm{HCl}_{(\mathrm{aq} .)}$ was added. Each mixture was allowed to stir at $\mathrm{rt}$ for several hours. The resulting precipitates were filtered (first enantiomer $0.53 \mathrm{~g}$, second enantiomer $0.31 \mathrm{~g}$ ). HPLC indicated that the acid dervied from the first diasteremoeric salt (the solid) had an enantiomeric excess of $82 \%$ while the acid derived from the filtrate had an enantiomeric excess of $89 \%$.

A Chiralpak AD(-H) column was used with an isopropyl alcohol : hexane $(20: 80)$ mixture as eluent at a flow rate of $1.0 \mathrm{ml} \mathrm{min}^{-1}$. Enantiomer 1 retention time $=13.18 \mathrm{~min}$. Enantiomer 2: retention time $=17.75 \mathrm{~min}$. See Supplementary Material for reproduction of traces. Enantiomer 1 had an er $=83: 17$ and enantiomer 2 had an er $=10: 90$. 
$N$-(3,5-Bis(trifluoromethyl)phenyl)-4-(p-toluenesulfonamido)[2.2]paracyclophane-

13-carbamide (32). To a suspension of 4-( $p$-toluenesulfonamido)[2.2]paracyclophane-13carboxylic acid ( $0.15 \mathrm{~g}$, $0.36 \mathrm{mmol}, 1.0$ eq.) in $\mathrm{CH}_{2} \mathrm{Cl}_{2}$ (3.5 ml) was added oxalyl chloride (0.04 ?l, $0.43 \mathrm{mmol}, 1.2 \mathrm{eq}$.) and a drop of DMF. The solution was allowed stirred for $3 \mathrm{hrs}$ at rt. The solvent was removed and the residue re-dissolved in toluene $(3.5 \mathrm{ml}) .3,5-$

Bis(trifluoromethyl)aniline (0.07 ?l, $0.43 \mathrm{mmol}, 1.2$ eq.) was added and the mixture heated to reflux overnight. The solvent was removed. The resulting residue was purified by column chromatography eluting Hex/EtOAc $2 / 1$ to afford the $N$-(3,5-bis(trifluoromethyl)phenyl)-4( $p$-toluenesulfonamido)[2.2] paracyclophane-13-carbamide 32 as a pale yellow solid (0.13 g, 57\%).

$\mathrm{R}_{\mathrm{f}}(2 / 1 \mathrm{Hex} /$ EtOAc $) 0.30$

${ }^{1} \mathrm{H}$ NMR (500 MHz, CDCl $)$ : ? $8.15(2 \mathrm{H}, \mathrm{s}), 7.91(1 \mathrm{H}, \mathrm{s}), 7.80(1 \mathrm{H}, \mathrm{s}), 7.68(1 \mathrm{H}, \mathrm{s}), 7.43(2 \mathrm{H}, \mathrm{d}$ $J=8.2 \mathrm{~Hz}), 7.37(1 \mathrm{H}, \mathrm{s}), 7.12(2 \mathrm{H}, \mathrm{d}, J=8.2 \mathrm{~Hz}), 6.89(1 \mathrm{H}, \mathrm{d}, J=1.8 \mathrm{~Hz}), 6.63(1 \mathrm{H}, \mathrm{dd}, J=7.8$, $1.8 \mathrm{~Hz}), 6.58(1 \mathrm{H}, \mathrm{d}, J=7.8 \mathrm{~Hz}), 6.54-6.51(2 \mathrm{H}, \mathrm{m}), 5.95(1 \mathrm{H}, \mathrm{d}, J=1.4 \mathrm{~Hz}), 3.75-3.62(2 \mathrm{H}, \mathrm{m})$, 3.13-2.94 (5H, m), $2.73(1 \mathrm{H}, \mathrm{ddd}, J=13.6,10.8,4.4 \mathrm{~Hz}), 2.34(3 \mathrm{H}, \mathrm{s}) .{ }^{13} \mathrm{C}$ NMR $(125 \mathrm{MHz}$, $\mathrm{CDCl}_{3}$ ): 团169.6, 143.1, 140.7, 140.2, 139.0, 138.7, 136.8, 136.5, 136.2, 135.7, 135.2, 134.5, $132.7,132.4,132.2,131.5,131.1,129.3,127.1,127.0,124.2,122.4,120.2,118.2,111.9,34.8$, $34.5,33.2,32.5,21.5$. Splitting by the fluorine causes the ${ }^{13} \mathrm{C}$ NMR to be more complex than normal. HRMS (EI) found: $[\mathrm{M}+\mathrm{Na}]^{+}, 655.1410 . \mathrm{C}_{32} \mathrm{H}_{26} \mathrm{~F}_{6} \mathrm{~N}_{2} \mathrm{NaO}_{3} \mathrm{~S}$ requires $[\mathrm{M}+\mathrm{Na}]^{+}$, 655.1461.

4-(p-Toluenesulfonamido)- $N$-((trifluoromethyl)sulfonyl)[2.2]paracyclophane-13carbamide (33). To a suspension of 4-( $p$-toluenesulfonamido)[2.2] paracyclophane-13carboxylic acid 31 (50 mg, $0.12 \mathrm{mmol}, 1.0$ eq.) in $\mathrm{CH}_{2} \mathrm{Cl}_{2}(1.2 \mathrm{ml}$ ) was added oxalyl chloride (12 ll, $0.14 \mathrm{mmol}, 1.2$ eq.) and a drop of DMF. The solution was stirred at rt for $3 \mathrm{~h}$. The solvent was removed and the residue dissolved in THF $(2 \mathrm{ml})$. To a solution of trifluoromethanesulfonamide ( $21 \mathrm{mg}, 0.14 \mathrm{mmol}, 1.2 \mathrm{eq}$.) in THF (1 ml) was added a suspension of $\mathrm{NaH}(60 \% ; 6 \mathrm{mg}, 0.24 \mathrm{mmol}, 2.0 \mathrm{eq}$.) followed by the solution of $4-(p-$ toluenesulfonamido)[2.2] paracyclophane-13-carbonyl chloride. The reaction mixture was stired at $\mathrm{rt}$ for $3 \mathrm{~h}$. The reaction mixture was cooled to $0{ }^{\circ} \mathrm{C}$ and $\mathrm{H}_{2} \mathrm{O}$ (two drops) added. The reaction mixture was diluted with $\mathrm{CH}_{2} \mathrm{Cl}_{2}(10 \mathrm{ml})$ and dried $\left(\mathrm{MgSO}_{4}\right)$ before the solvent was removed. The resulting residue was separated by column chromatography eluting Hex/EtOAc 2/1 to afford the 4-( $p$-toluenesulfonamido)- $N$ -

((trifluoromethyl)sulfonyl)[2.2]paracyclophane-13-carbamide 33 as a brown solid (36 mg, $56 \%)$.

$\mathrm{R}_{\mathrm{f}}\left(20 / 1 ; \mathrm{CH}_{2} \mathrm{Cl}_{2} / \mathrm{MeOH}\right) 0.3$

${ }^{1} \mathrm{H} \mathrm{NMR}\left(500 \mathrm{MHz}, \mathrm{CDCl}_{3}\right)$ : 2017.68 (1H, s), $7.43(2 \mathrm{H}, \mathrm{d}, J=8.2 \mathrm{~Hz}), 7.40(1 \mathrm{H}, \mathrm{d}, J=1.8 \mathrm{~Hz})$, $7.07(2 \mathrm{H}, \mathrm{d}, J=8.2 \mathrm{~Hz}), 6.73(1 \mathrm{H}, \mathrm{dd}, J=7.8,1.8 \mathrm{~Hz}), 6.60(1 \mathrm{H}, \mathrm{d}, J=7.8 \mathrm{~Hz}), 6.52(1 \mathrm{H}, \mathrm{d}, J=$ $7.8 \mathrm{~Hz}), 6.36(1 \mathrm{H}, \mathrm{dd}, J=7.8,1.8 \mathrm{~Hz}), 6.24(1 \mathrm{H}, \mathrm{d}, J=1.6 \mathrm{~Hz}), 4.43-4.35(1 \mathrm{H}, \mathrm{m}), 3.84-3.75$ $(1 \mathrm{H}, \mathrm{m}), 3.17-2.86(6 \mathrm{H}, \mathrm{m}), 2.29(3 \mathrm{H}, \mathrm{s}) .{ }^{13} \mathrm{C} \mathrm{NMR}\left(125 \mathrm{MHz}, \mathrm{CDCl}_{3}\right)$ : 目目172.2, 143.9, 143.4, 
$140.8,139.6,137.0,136.5,136.4,136.1,135.8,135.4,134.6,131.2,129.4,128.6,128.2$, 127.3, 35.5, 34.9, 34.8, 31.1, 21.6 (includes fluorine splitting).

\section{Acknowledgements}

The authors thank Massey University for financial support (GJR), a Massey Vice Chancellor's Doctoral Scholarship (LE), a Massey University Technician Award (GK), and the Ecole Nationale Supérieure de Chimie de Rennes for support (LD).

\section{Notes and references}

₹ We have previously found BINAP to be the optimum ligand for the coupling of anilines to ortho-substituted [2.2] paracyclophane triflates. ${ }^{59}$ This demonstrates the substrate sensitivity of Buchwald-Hartwig couplings.

† This yield is based on a yield of $90 \%$ and $97 \%$ for the synthesis of [2.2] paracyclophane-4carboxylic acid and its methyl esterification respectively (average yields) then the highest yields for each of the subsequent steps.

$\S$ We briefly studied the amination reaction with L-proline. We noted a slight improvement in conversion but there was no indication by HPLC or circular dichroism of the isolated amine that there had been any enrichment.

$\S \S$ The transannular effect guides electrophilic aromatic substitution to the pseudo-gem position. ${ }^{60}$ Bromination gives the best results. There are examples of chloromethylation ${ }^{61}$ and the Rieche formylation ${ }^{17}$ while pseudo-gem nitration met with limited success. ${ }^{53}$

1 O. R. P. David, Tetrahedron, 2012, 68, 8977; J. Paradies, Synthesis, 2011, 3749.

2 R. Gleiter and H. Hopf, eds., Modern Cyclophane Chemistry, Wiley-VCH, Weinheim, 2004.

3 G. J. Rowlands, Org. Biomol. Chem., 2008, 6, 1527.

4 S. E. Gibson and J. D. Knight, Org. Biomol. Chem., 2003, 1, 1256; V. Rozenberg, E. Sergeeva and H. Hopf, in Modern Cyclophane Chemistry, eds. R. Gleiter and H. Hopf, WileyVCH, Weinheim, 2004, pp. 435.

$5 \quad$ P. Mücke, R. F. Winter, I. Novak and K. Kowalski, J. Organomet. Chem., 2012, 717, 14.

6 G. C. Bazan, J. Org. Chem., 2007, 72, 8615; L. Valentini, F. Mengoni, A. Taticchi, A. Marrocchi, S. Landi, L. Minuti and J. M. Kenny, New. J. Chem., 2006, 30, 939.

7 S. Clement, T. Goudreault, D. Bellows, D. Fortin, L. Guyard, M. Knorr and P. D. Harvey, Chem. Commun., 2012, 48, 8640.

8 J. Lahann, H. Höcker and R. Langer, Angew. Chem. Int. Ed., 2001, 40, 726; J. Lahann, D. Klee and H. Höcker, Macromol. Rapid Commun., 1998, 19, 441. 
9 H.-W. Chien, M.-C. Keng, M.-J. Wang, H.-Y. Chen, S.-T. Huang and W.-B. Tsai, Langmuir, 2014, 30, 14257.

10 M. Skultety, H. Hübner, S. Löber and P. Gmeiner, J. Med. Chem., 2010, 53, 7219.

11 K. Schlotter, F. Boeckler, H. Hübner and P. Gmeiner, J. Med. Chem., 2006, 49, 3628; S. Löber, B. Ortner, L. Bettinetti, H. Hübner and P. Gmeiner, Tetrahedron: Asymmetry, 2002, 13, 2303.

12 J. F. Schneider, R. Fröhlich and J. Paradies, Isr. J. Chem., 2012, 52, 76.

13 A. Pelter, R. A. N. C. Crump and H. Kidwell, Tetrahedron: Asymmetry, 1997, 8, 3873.

14 G. Ciancaleoni, G. Bellachioma, G. Cardaci, G. Ricci, R. Ruzziconi, D. Zuccaccia and A. Macchioni, J. Organomet. Chem., 2006, 691, 165; N. De Rycke, J. Marrot, F. Couty and O. R. P. David, Eur. J. Org. Chem., 2011, 1980; K. M. El-Shaieb, A.-F. E. Mourad, A. A. A. Hopf and Henning, ARKIVOC, 2006, (ii), 193; P. K. Hashim, M. C. Basheer and N. Tamaoki, Tetrahedron Lett., 2013, 54, 176; G. Ricci and R. Ruzziconi, Tetrahedron: Asymmetry, 2005, 16, 1817; G. Ricci, R. Ruzziconi and E. Giorgio, J. Org. Chem., 2005, 70, 1011; K. Rijeesh, P. K. Hashim, S.-i. Noro and N. Tamaoki, Chem. Sci., 2015, 6, 973; P. Schooler, B. F. G. Johnson and S. Parsons, J. Chem. Soc., Dalton Trans., 1999, 559; Kamal E. Shaieb, V. Narayanan, H. Hopf, I. Dix, A. Fischer, Peter G. Jones, L. Ernst and K. Ibrom, Eur. J. Org. Chem., 2003, 567; H. Hopf, S. V. Narayanan and P. G. Jones, Beilstein J. Org. Chem. 2015, 11, 437.

15 B. Hong, Y. Ma, L. Zhao, W. Duan, F. He and C. Song, Tetrahedron: Asymmetry, 2011, 22, 1055.

16 A. Marchand, A. Maxwell, B. Mootoo, A. Pelter and A. Reid, Tetrahedron, 2000, 56, 7331.

17 H. Zitt, I. Dix, H. Hopf and P G. Jones, Eur. J. Org. Chem., 2002, 2298.

18 J. F. Schneider, F. C. Falk, R. Fröhlich and J. Paradies, Eur. J. Org. Chem., 2010, 2265.

19 H. Falk and K. Schlögl, Angew. Chem. Int. Ed. Engl., 1968, 7, 383; H. Falk, P. ReichRohrwig and K. Schlögl, Tetrahedron, 1970, 26, 511; V. Rozenberg, N. Dubrovina, E. Sergeeva, D. Antonov and Y. Belokon, Tetrahedron: Asymmetry, 1998, 9, 653; B. Jiang, X.-L. Zhao and X.-Y. Xu, Tetrahedron: Asymmetry, 2005, 16, 1071.

20 A. Cipiciani, F. Fringuelli, V. Mancini, O. Piermatti, F. Pizzo and R. Ruzziconi, J. Org. Chem., 1997, 62, 3744.

21 A. Cipiciani, F. Fringuelli, O. Piermatti, F. Pizzo and R. Ruzziconi, J. Org. Chem., 2002, 67, 2665.

22 S. Clément, L. Guyard, M. Knorr, S. Dilsky, C. Strohmann and M. Arroyo, J. Organomet. Chem., 2007, 692, 839; V. Göker, S. R. Kohl, F. Rominger, G. Meyer-Eppler, L. Volbach, G. Schnakenburg, A. Lützen and A. S. K. Hashmi, J. Organomet. Chem., 2015, 795, 45; D. S. 
Masterson and D. T. Glatzhofer, J. Mol. Catal. A: Chem., 2000, 161, 65; D. S. Masterson, T. L. Hobbs and D. T. Glatzhofer, J. Mol. Catal. A: Chem., 1999, 145, 75; D. S. Masterson, C. Shirley and D. T. Glatzhofer, J. Mol. Catal. A: Chem., 2012, 361-362, 111; L. Zhao, Y. Ma, W. Duan, F. He, J. Chen and C. Song, Org. Lett., 2012, 14, 5780; ～L. Zhao, Y. Ma, F. He, W. Duan, J. Chen and C. Song, J. Org. Chem., 2013, 78, 1677.

23 G. Meyer-Eppler, R. Sure, A. Schneider, G. Schnakenburg, S. Grimme and A. Lützen, J. Org. Chem., 2014, 79, 6679.

24 J. E. Glover, D. J. Martin, P. G. Plieger and G. J. Rowlands, Eur. J. Org. Chem., 2013, 1671.

25 P. B. Hitchcock, G. J. Rowlands and R. Parmar, Chem. Commun., 2005, 4219.

26 P. B. Hitchcock, G. J. Rowlands and R. J. Seacome, Org. Biomol. Chem., 2005, 3, 3873.

27 D. S. Surry and S. L. Buchwald, Chem. Sci., 2011, 2, 27; J. F. Hartwig, Nature, 2008, 455, 314; B. Schlummer and U. Scholz, Adv. Synth. Catal., 2004, 346, 1599.

28 P. J. Ball, T. R. Shtoyko, J. A. Krause Bauer, W. J. Oldham and W. B. Connick, Inorg. Chem., 2004, 43, 622.

29 J. Chen, S. Yang, Z. Chen, C. Song and Y. Ma, Tetrahedron: Asymmetry, 2015, 26, 288; W. Duan, Y. Ma, F. He, L. Zhao, J. Chen and C. Song, Tetrahedron: Asymmetry, 2013, 24, 241; W. Duan, Y. Ma, Y. Huo and Q. Yao, Aust. J. Chem., 2015, 68, 1472; W. Duan, Y. Ma, B. Qu, L. Zhao, J. Chen and C. Song, Tetrahedron: Asymmetry, 2012, 23, 1369; S. Kitagaki, Y. Ohta, S. Tomonaga, R. Takahashi and C. Mukai, Tetrahedron: Asymmetry, 2011, 22, 986; S. Kitagaki, T. Ueda and C. Mukai, Chem. Commun., 2013, 49, 4030; M. Kreis, M. Nieger and S. Bräse, J. Organomet. Chem., 2006, 691, 2171; Y. Lu, Y. Ma, S. Yang, M. Ma, H. Chu and C. Song, Tetrahedron: Asymmetry, 2013, 24, 1082; Y. Ma, C. Song, C. Ma, Z. Sun, Q. Chai and M. B. Andrus, Angew. Chem. Int. Ed., 2003, 42, 5871; Z. Niu, J. Chen, Z. Chen, M. Ma, C. Song and Y. Ma, J. Org. Chem., 2015, 80, 602; B. Ortner, H. Hübner and P. Gmeiner, Tetrahedron: Asymmetry, 2001, 12, 3205; B. Ortner, R. Waibel and P. Gmeiner, Angew. Chem. Int. Ed., 2001, 40, 1283; I. Piel, J. V. Dickschat, T. Pape, F. E. Hahn and F. Glorius, Dalton Trans, 2012, 41, 13788; P. Schaal née Lennartz, H. Baars, G. Raabe, I. Atodiresei and C. Bolm, Adv. Synth. Catal., 2013, 355, 2506.

30 M. Kreis, C. J. Friedmann and S. Bräse, Chem. Eur. J., 2005, 11, 7387.

31 P. Lennartz, G. Raabe and C. Bolm, Adv. Synth. Catal., 2012, 354, 3237.

32 P. Lennartz, G. Raabe and C. Bolm, Isr. J. Chem., 2012, 52, 171.

33 Q. Ma, Y. Ma, X. Liu, W. Duan, B. Qu and C. Song, Tetrahedron: Asymmetry, 2010, 21, 292.

34 B. Qu, Y. Ma, Q. Ma, X. Liu, F. He and C. Song, J. Org. Chem., 2009, 74, 6867. 
35 F. Sanna, B. Ortner, H. Hubner, S. Lober, N. Tschammer and P. Gmeiner, Bioorg. Med. Chem., 2013, 21, 1680.

36 S. R. Chemler, Science, 2013, 341, 624; K. Okano, H. Tokuyama and T. Fukuyama, Chem. Commun., 2014, 50, 13650.

37 J. R. Fulton, J. E. Glover, L. Kamara and G. J. Rowlands, Chem. Commun., 2011, 47, 433;

J. E. Glover, P. G. Plieger and G. J. Rowlands, Aust. J. Chem., 2014, 67, 374; G. J.

Rowlands and R. J. Seacome, Beilstein J. Org. Chem., 2009, 5, doi:10.3762/bjoc.5.9.

38 R. Parmar, M. P. Coles, P. B. Hitchcock and G. J. Rowlands, Synthesis, 2010, 4177.

39 R. J. Seacome, M. P. Coles, J. E. Glover, P. B. Hitchcock and G. J. Rowlands, Dalton Trans., 2010, 39, 3687.

40 W. Zhu and D. Ma, Chem. Commun., 2004, 888; Y. Goriya and C. V. Ramana, Tetrahedron, 2010, 66, 7642; Y. A. Cho, D.-S. Kim, H. R. Ahn, B. Canturk, G. A. Molander and J. Ham, Org. Lett., 2009, 11, 4330.

41 J. T. Markiewicz, O. Wiest and P. Helquist, J. Org. Chem., 2010, 75, 4887.

42 T. Sperger, I. A. Sanhueza, I. Kalvet and F. Schoenebeck, Chem. Rev., 2015, 115, 9532;

E. Sperotto, G. P. M. van Klink, G. van Koten and J. G. de Vries, Dalton Trans., 2010, 39, 10338.

43 C. J. Friedmann, S. Ay and S. Bräse, J. Org. Chem., 2010, 75, 4612.

44 V. Rozenberg, R. Zhuravsky and E. Sergeeva, Chirality, 2006, 18, 95.

45 S. Banfi, A. Manfredi, F. Montanari, G. Pozzi and S. Quici, J. Mol. Catal. A: Chem., 1996, 113, 77.

46 H. Ghosh, A. Baneerjee, S. K. Rout and B. K. Patel, ARKIVOC, 2011, (ii), 209.

47 H. Ghosh and B. K. Patel, Org. Biomol. Chem., 2010, 8, 384.

48 G. F. Koser and R. H. Wettach, J. Org. Chem., 1977, 42, 1476.

49 Y. Hoshino, M. Okuno, E. Kawamura, K. Honda and S. Inoue, Chem. Commun., 2009, 2281; Y. Hoshino, Y. Shimbo, N. Ohtsuka and K. Honda, Tetrahedron Lett., 2015, 56, 710; S. Yoganathan and S. J. Miller, Org. Lett., 2013, 15, 602.

50 H. Allgeier, M. G. Siegel, R. C. Helgeson, E. Schmidt and D. J. Cram, J. Am. Chem. Soc., 1975, 97, 3782; D. Xin, Y. Ma and F. He, Tetrahedron: Asymmetry, 2010, 21, 333; J. F. Schneider, R. Fröhlich and J. Paradies, Synthesis, 2010, 3486; F. He, Y. Ma, L. Zhao, W. Duan, J. Chen and C. Song, Org. Lett., 2012, 14, 5436; D. Wang, Y. Ma, F. He, W. Duan, L. Zhao and C. Song, Synth. Commun., 2013, 43, 810.

51 W. Duan, Y. Ma, H. Xia, X. Liu, Q. Ma and J. Sun, J. Org. Chem., 2008, 73, 4330. 
52 M. Psiorz and R. Schmid, Chem. Ber., 1987, 120, 1825.

53 A. Pelter, R. A. N. C. Crump and H. Kidwell, Tetrahedron Lett., 1996, 37, 1273.

54 V. Rozenberg, T. y. Danilova, E. Sergeeva, E. Vorontsov, Z. Starikova, A. Korlyukov and H. Hopf, Eur. J. Org. Chem., 2002, 468.

55 J. J. P. Kramer, C. Yildiz, M. Nieger and S. Bräse, Eur. J. Org. Chem., 2014, 1287.

56 K. Moriyama, T. Sugiue, Y. Saito, S. Katsuta and H. Togo, Adv. Synth. Catal., 2015, 357, 2143.

57 L. M. Yagupolskii, V. N. Petrik, N. V. Kondratenko, L. Soovali, I. Kaljurand, I. Leito and I. A. Koppel, J. Chem. Soc., Perkin Trans. 2, 2002, 1950; A. Kütt, I. Leito, I. Kaljurand, L. Sooväli, V. M. Vlasov, L. M. Yagupolskii and I. A. Koppel, J. Org. Chem., 2006, 71, 2829.

58 A. A. Aly, H. Hopf, P. G. Jones and I. Dix, Tetrahedron, 2006, 62, 4498; E. H. Eltamany, Indian J. Chem. Sect B-Org. Chem. Incl. Med. Chem., 1992, 31, 238.

59 P. B. Hitchcock, A. C. C. Hodgson and G. J. Rowlands, Synlett, 2006, 2625.

60 F. Vögtle, Cyclophane Chemistry, Wiley, Chichester, 1993; D. J. Cram and J. M. Cram, Acc. Chem. Res., 1971, 4, 204.

61 E. A. Truesdale and D. J. Cram, J. Org. Chem., 1980, 45, 3974. 